Illinois State University

ISU ReD: Research and eData

Theses and Dissertations

$1-28-2021$

\title{
The Crisis Of Democracy: The Case Study Of Democratic Backsliding And The Rise Of Populism In Poland
}

Nargiza Yusupova

Illinois State University, y.nargiza@yahoo.com

Follow this and additional works at: https://ir.library.illinoisstate.edu/etd

Part of the International Relations Commons

\section{Recommended Citation}

Yusupova, Nargiza, "The Crisis Of Democracy: The Case Study Of Democratic Backsliding And The Rise Of Populism In Poland" (2021). Theses and Dissertations. 1421.

https://ir.library.illinoisstate.edu/etd/1421

This Thesis is brought to you for free and open access by ISU ReD: Research and eData. It has been accepted for inclusion in Theses and Dissertations by an authorized administrator of ISU ReD: Research and eData. For more information, please contact ISUReD@ilstu.edu. 


\section{THE CRISIS OF DEMOCRACY: THE CASE STUDY OF DEMOCRATIC BACKSLIDING AND THE RISE OF POPULISM IN POLAND}

\section{NARGIZA YUSUPOVA}

\section{Pages}

Poland made impressive gains during its democratization phrase between 1989 and 2015. Its economy became significantly more open; formal institutions underwent dramatic changes in checks and balances. Yet the task of sustaining the impressive performance of democratic institutions has become increasingly difficult after the victory of the Law and Justice Party (PiS) party during the 2015 elections. A right-wing populist PiS party's rise to power had clear political mainsprings. A number of changes and amendments to the Constitutional Tribunal Act have been introduced that threaten the Tribunal independence and put constraints on the independence of the media, civil service, police, and prosecution. Along with many academic scholars, politicians, NGOs, activists for democracy, including those in the European Commission, condemned the Law and Justice Party's move, calling it an attempt to dismantle institutional checks on the government and erode civil and political rights.

From Poland's democratic regression, we can learn that declines in democracy scores are not always the result of an institution's instability or mismanaged government. When civil society disbelief for the government officials is accompanied by other structural features of vulnerability, a high risk of democratic backsliding arises, as exemplified in this thesis. The underlying exposure to Poland's backsliding depends on a host of factors, including weak civil society, low public trust 
in democratic institutions, a history of unrest, high political polarization, and, primarily, discourses of political parties. Rising popular frustration with the political status quo in Poland led to the rise of the right-wing Populist Party, the PiS, and reflected negatively in the overall score of democracy. This thesis aimed to determine to what extent the rise and victory of the right-wing Populist Party, the PiS, has impacted democratic backsliding in the country. By studying the rise of populism in relation to democratic backsliding in Poland, this thesis aims to offer an alternative framework to the social requisites literature for understanding how elected officials can reverse democratization.

KEYWORDS: democratic backsliding, democratization, Poland, populism, democratic consolidation, autocratization 
THE CRISIS OF DEMOCRACY: THE CASE STUDY OF DEMOCRATIC BACKSLIDING

AND THE RISE OF POPULISM IN POLAND

NARGIZA YUSUPOVA

A Thesis Submitted in Partial

Fulfillment of the Requirements

for the Degree of

MASTER OF SCIENCE

Department of Politics and Government

ILLINOIS STATE UNIVERSITY

2021 
Copyright 2021 Nargiza Yusupova 
THE CRISIS OF DEMOCRACY: THE CASE STUDY OF DEMOCRATIC BACKSLIDING AND THE RISE OF POPULISM IN POLAND

NARGIZA YUSUPOVA

COMMITTEE MEMBERS:

Ali Riaz, Chair

Yusuf Sarfati

Kam Shapiro 


\section{ACKNOWLEDGMENTS}

Here I would like to thank my committee members for their collective support and time in helping me develop, improve, and finalize this thesis. Also, I would like to acknowledge the Department of Politics and Government for their enormous support and mentorship that have enriched my graduate experience. Lastly and mostly, I would like to thank my family for their support and trust in me.

N. Y. 
$\begin{array}{ll}\text { CONTENTS ii } & \text { ii }\end{array}$

TABLES $\quad$ iv

CHAPTER I: INTRODUCTION 1

Background: Democratic Recession - A Global Trend? 3

Democratization Theory $\quad 5$

$\begin{array}{ll}\text { Polish Political System } & 9\end{array}$

$\begin{array}{ll}\text { Theoretical Framework } & 13\end{array}$

$\begin{array}{ll}\text { Democratic Consolidation } & 13\end{array}$

$\begin{array}{ll}\text { Democratic Backsliding } & 15\end{array}$

$\begin{array}{ll}\text { Hybrid Regimes } & 16\end{array}$

$\begin{array}{ll}\text { Populism } & 19\end{array}$

$\begin{array}{ll}\text { Elections } & 21\end{array}$

$\begin{array}{ll}\text { Methodology } & 23\end{array}$

CHAPTER II: HOW TO DEFINE THE CURRENT REGIME IN POLAND? 25

$\begin{array}{ll}\text { Explanation in Mainstream Literature } & 25\end{array}$

The Case of Poland as a Hybrid Regime $\quad 29$

The discourse of the PiS party 33

CHAPTER III: THE PATH TO DEMOCRACY: POLAND 1989-2015 38

The Roundtable Agreement 38 
Steps towards Democratization

Constitutional Changes $\quad 45$

NATO and EU Accessions as an External Anchor for Democratization 48

$\begin{array}{ll}\text { Conclusions } & 51\end{array}$

CHAPTER IV: WHAT HAS GONE WRONG WITH DEMOCRACY IN POLAND? 56

Polish Political Landscape Before 2015

PiS Party during 2015 Elections $\quad 58$

Changes Introduced to the Institutions of Democracy 63

$\begin{array}{ll}\text { How It Happened } & 68\end{array}$

CHAPTER V: CONCLUSION

$\begin{array}{ll}\text { REFERENCES } & 79\end{array}$

APPENDIX: JAROSLAW KACZYNSKI AND HIS ROLE IN POLISH POLITICS 83 


\section{TABLES}

Table

Page

1. Parties and Voting in Poland in 1991-2015

2. Nations in Transit: Poland 2005-2015

3. Nations in Transit 2016-2020: Category and Democracy Score Summery

4. Nations in Transit 2020: Democracy Score Summery

5. Poland's Ten-Year Decline 


\section{CHAPTER I: INTRODUCTION}

Since 2015, the year the Law and Justice (PiS) party won both the presidential and parliamentary elections, dramatic changes have occurred in Polish constitutional politics. A number of changes and amendments ${ }^{1}$ to the Constitutional Tribunal Act have been introduced that threaten the Tribunal independence and put constraints on the independence of the media, civil service, police, and prosecution. Along with many academic scholars, politicians, NGOs, activists for democracy, including those in the European Commission, condemned the Law and Justice Party's move, calling it an attempt to dismantle institutional checks on the government and erode civil and political rights. This thesis aims to provide an overview of these developments in Poland, and explore how and why Polish democracy is regressing. This thesis intends to answer the following question:

1) How did Poland, a country that was considered to have made significant progress in the democratization process and was considered a successful democracy, turn into a 'hybrid regime'2 in four years (2015-2019)? What prompted the backsliding in Poland?

The principal objective of this thesis is twofold.

First, it tests theories of democratic erosion with the case study of Poland. A close examination and review of some fundamental theoretical categories such as democratization and autocratization, hybrid regimes, elections, and discourses of populism are required to achieve this objective. Considering that the category "hybrid regime" is multifaceted and a

\footnotetext{
${ }^{1}$ Article 5.5 of the Constitutional Tribunal Act stipulates that a person elected to the office of a judge shall take the oath from the President of the Republic of Poland. The refusal to take the oath shall be equivalent to a resignation from the office of a judge of the Tribunal (Art 5.6). On 19 November 2015, the newly-composed Parliament amended the Law with respect to the Constitutional Tribunal, which inter alia enabled previously appointed judges' dismissal. On November 25 the Parliament annulled the election of all five judges, and a week later, on December 2, resolved to appoint five new judges, from whom the President took the oath immediately, Sava Jankovich 2016.

${ }^{2}$ Ali Riaz 2020, Voting in a Hybrid Regime, Matthijs Bogaards 2009 How to classify hybrid regimes? Defective democracy and electoral authoritarianism.
} 
wide variety of non/semi-democratic systems are considered to fall within the category, I will examine only "defective democracies"3 (Bogaards, 2009) within the hybrid regime category in relation to Poland.

This thesis's second objective is to offer an alternative framework of analysis for understanding democratic backsliding by looking at populism as a possible contributory factor to the phenomenon. Reference to backsliding and populism in Poland in the same breath should not presume that the rise of populism is a contributory factor to democratic recession in other countries too. Rather, Poland's case study is expected to contribute to an understanding of democratic regression and identify factors contributing to backsliding. Further, the case study of Polish backsliding may help identify the danger of backsliding in countries displaying similar warning signs.

Hubert Tworzecki (2019) describes the backsliding in Poland due to polarization built top-down rather than bottom-up by the radical populist, anti-establishment political class. The uniqueness of the Polish case lies in its defiance of decades of accumulated political science research on the democratization process. Poland's democratic backsliding does not display any of the major risk factors identified by previous literature, such as lack of economic growth, stark racial and ethnic divisions, vulnerable institutional structure (e.g., presidentialism, electoral college), or external factors (e.g., neighbor non-democracies, trade dependency) that could be reasons behind backsliding (Tworzecki, 2019, 98). On the contrary, since the collapse of the USSR, Poland has witnessed its per capita income increase and was even identified as the least affected country in the EU during the 2008 financial crisis. Unemployment in 2015

\footnotetext{
3 "A defective democracy is a regime defined by a largely functioning democratic electoral regime for the selection of rulers that, however, through disruptions in the operating logic of one or more of the other components (e.g., elections, political participation rights, civil rights, horizontal accountability and effective government) loses the complementary buttresses which in a functioning democracy are indispensable for securing freedom, equality and control" (Bogaards, 2009, p. 7).
} 
was the lowest in decades, along with consistent income growth, making economic inequality moderate in society.

Based on the institutional structure, thanks to the parliamentary system and proportional electoral law, which are safeguards of democracy against authoritarian ambitions, Poland should not have experienced backsliding. Moreover, Poland's new Constitution (1997) includes a comprehensive set of checks and balances, with external constraints from the EU (Tworzecki, 2019, 98).

The democratization process from 1989 to 2015 should have provided sufficient time to consolidate democratic norms. In other words, 26 years of transition should have been enough to produce system stabilization and self-reinforcing dynamics for democratic consolidation. In terms of external factors, the European Union membership should have been an anchor for democratization. The 'structuralist' (Sadurski, 2019, p. 162) explanation for the democratic regression cannot be applied to Poland, and therefore, the Polish case presents a puzzle to explain its backsliding.

In this thesis I argue that despite the aforementioned highly favorable circumstances, Poland's democratization process regressed after the PiS party's victory in the elections of 2015. Except Hungary, nowhere else in Europe has governing parties managed to assault the institutional system of checks and balances as happened in Poland during the PiS party's governance.

\section{Background: Democratic Recession - A Global Trend?}

By 2006, the number of democracies had reached 86 (Diamond, 2020), and there was an overall increase in the number of people living under democracy. Still, the democratization 
process had stalled in many countries. According to Freedom House reports, global levels of political rights and civil liberties indicators have been undergoing a gradual decline for 14 consecutive years ${ }^{4}$. Two decades of scholarship on third-wave democracies have documented the palpable corrosion of democratic institutions and norms in many countries. It is now commonly agreed that democracy is facing a global crisis. While it is not the first-time democracy has undergone a crisis, this time is different. The institutions and culture that have shaped liberal democracy are being undermined and eroded from within by elected leaders ${ }^{5}$.

In the 1940s, by contrast, the crisis came from internal pushback from individual citizens against the conventional practices of democracy. In other words, public participation in state's political policies had increased, altering the democratization process to accommodate the growth of an increasingly active civil society. Compared to the 1940s crisis, the nature of the crisis in the 1970s was about external ideologies, questioning the legitimacy of democratic rule in the country. Additionally, the newly found communist style of governance put more doubts on democracy, with economic inflation exacerbating the crisis further.

In recent years, threats to democracy have been coming from within the political system and through the increasing popular appeal of polarizing politicians. Recent global financial, and refugee, crises have stimulated intolerant anti-immigrant populist movements in Europe and the United States. Political parties have become extremely polarized and divided, fostering public distrust of governing institutions. Voter turnout is falling (Solijonov, 2016), hostility against immigrants is growing (Girdusky, 2019), and elected leaders have been attacking the independence of the courts, the media, civil society, and private institutions that criticize their administration (Jankovich, 2016).

\footnotetext{
${ }^{4}$ Sarah Repucci "A Leaderless Struggle for Democracy" Freedom in the World Report 2020.

${ }^{5}$ Viktor Orban's government in Hungary, Trump's attacks on established institutions are examples.
} 
In these respects, the democratic recession in Poland is not exclusive, and the country resembles other third-wave democracies that are stuck in what analysts call a "grey zone" (Carothers 2002, USAID 2015, Mufti 2018). According to Mufti, grey-zone countries retain some democracy attributes, such as regular elections, some political freedom, opposition, and democratic constitutions. However, they do not possess institutions representing minority groups, government officials frequently abuse laws, elections are often manipulated, state institutions have low levels of public trust, and institutional performance is poor (Mufti, 2018).

\section{Democratization Theory}

According to Carothers, a country moving away from an authoritarian rule can be considered a country in a transition toward democracy or, in other words, embarked on the 'democratization' process. Carothers distinguishes three stages of change in the transitional period: opening, breakthrough, and consolidation (Carothers, 2002, p. 7).

The first stage, opening, is marked by a crack in the dictatorial rule and mass mobilization. This follows the breakthrough period, where an old authoritarian system of governance collapses, and democratic institutional structures are built. In this stage, the democratic system is often established through the promulgation of a new constitution. Once an old system is replaced with a new, more liberal and democratic system, the democratic consolidation process is expected to begin. During the democratic consolidation process, state institutions undergo reforms and establish new forms of democratic institutions. These institutions serve to regulate elections, strengthen civil society, and install democratic rules of the game. The democratization process is a gradual modification of the political system that aims to restore democracy. Since the beginning of the 'third wave of democratization' (Huntington, 1991) in 1974, approximately 100 countries (Carothers 2002, Luhrmann and Lindberg 2019, Diamond 
2002) are considered in transitional mode and have made some democratic progress. However, Carothers argued in 2002 that only 20 of these countries are on a path to progress and expect to become successful and well-functioning democracies. The question arises: what is the fate of the remaining states where the transition paradigm is still underway?

Many countries considered in a transitional period show some democratic features, but these signs are often illusory and do not follow the democratization paradigm. For example, the belief that regular, genuine, and fair elections will confer democratic legitimacy on new governments and further strengthen political participation and democratic accountability has been proven wrong. In other words, despite regular and competitive elections in many transition countries, political participation remains low, and hence governmental accountability is poor. Additionally, in many countries, authoritarian leaders attempt to manipulate elections results.

Second, despite pre-conditions for democracy being dismissed by enthusiastic democracy promoters, the reality shows that various structural conditions shape political outcomes. We have to look back to most third-wave countries' political trajectories to predict the success of the democratization progress. For example, post-communist Central Asian nations failed in their first, opening stage due to their historical trajectories. Many of the predecessor regimes' institutional legacies proved to be resilient, and thus strongly have impeded democratization. These countries also have relatively low economic wealth and no prior experience with political pluralism. The patrimonial political society system is another block to the democratization process. The relationship between political elites and leaders is a patron-client relationship, which hinders fostering successful political actions.

Third, democracy promoters' tendency to focus on political processes and institutions has faced fundamental state-building challenges. Many states have either not had core national 
state institutions or existing institutions were highly corrupted. An absence of strong core institutions has created a system of feckless pluralism and dominant power politics. In a feckless pluralism system, political systems tend to have political freedom, regular elections, and a considerable amount of opposition power. However, many political elites are perceived to be corrupt, self-serving, and ineffective in representing citizens' interests. Thus, the public has no confidence in officials, and the state remains weak and unable to solve the significant problems the governments are facing. In dominant power politics, by contrast, there is only one ruling political force and a one-sided grip on power. State performance is poor, and there is no public trust.

According to Carothers, Poland was among the most successful post transitional democracies in Central Eastern Europe after the Soviet Union's collapse in 1989 (Carothers, 2002, p. 9). The events of 1989 marked a turning point in the history of Poland. The dissolution of the Soviet Union and the Roundtable Agreement ${ }^{6}$ between the opposition and the government played a crucial role in starting the process of transition to democracy in Poland. One of the key elements of the process was holding a free, fair, multi-party, inclusive election. In elections held on June 4, 1989, Solidarity ${ }^{7}$, the labor union that spearheaded the democracy movement, was overwhelmingly victorious, winning the majority of seats in both the lower and upper houses. After the election, the Communist Polish United Workers Party (PUWP),

\footnotetext{
${ }^{6}$ On $5^{\text {th }}$ April, 1989, two months after official negotiations began, Solidarity and the government met at the roundtable to accept the following agreements: 1 ) restoration of Solidarity and the promise of legalization for an independent students' union; 2) elections on4th June 4, 1989, for a two-house parliament, in which free competition would be permitted for $35 \%$ of the 460 seats in the existing lower house, the Sejm; 3 ) restoration of the upper house (the senate) disbanded after WWII, with a hundred members chosen in completely free elections. The upper house would have veto over the lower house; 4) establishment of the office of 'president of the republic,' elected by the two houses of Parliament for a six-year term, with broad powers to dissolve Parliament and veto laws passed by the lower house (able to be overturned by two-thirds vote); 5) changes in the structure of the economy. This agreement between the government and Solidarity was called the Roundtable Talks, which paved the way towards democracy. ${ }^{7}$ Solidarity is a Polish labor union that was founded on 17 September 1980 at the Lenin Shipyard in Gdansk under the leadership of Lech Walesa. It was the first trade union in a Warsaw Pact country that was not controlled by a communist party.
} 
which had governed the Polish People's Republic for 41 years since 1948, failed to form a government. The Solidarity union formed a coalition with other post-communist parties. The All-Poland Alliance of Trade Unions (OPZZ), the United Peasants Association (ZSL), and the Democratic Party (SD) united and proposed a former dissident, Tadeusz Mazowiecki, as prime minister. Mazowiecki became the first non-communist elected head of the government on 24 August, 1989 (Osiatynski, 1996, pp 50-54). Following this, the new government introduced a series of reforms in agriculture, education, and health care. Censorship was eased, freedom of the press was extended, judicial independence was restored, and a new law on associations were adopted. Most importantly, economic reforms that mandated that all money received from overseas donations would be transferred to private foundations such as trade unions rather than to the Communist state treasury escalated country's breakdown of communist rule.

Between 1989 and 2015, Poland attained democratic governance generated by free and fair elections, achieved better living standards, and secured a membership in both NATO (1999) and the EU (2004). The transition from communist-dictatorship to democracy occurred peacefully in carefully negotiated increments. However, the PiS party's victory during the 2015 elections marked a turning point in Poland's history. In 2015, Andrej Duda and his party, the PiS, won both presidential and parliamentary elections. In the aftermath of its victory, the party introduced changes to the Constitution that threatened the rule of law and accelerated backsliding in Poland. There are warning signs in Poland of a vital deterioration in democratic features already attained during the democratization period. Changes and amendments introduced in the Constitutional Tribunal, judiciary, and the new Police Act law will be discussed in greater depth in the thesis's body. Many political science scholars find that the PiS party's tactics during and after elections resembled those of political leaders' strategies that show signs of populism. For instance, Trump's victory in the presidential election in 2016 in the United States marked a turning point in the triumph of demagogic leadership and the 
aftermath crisis of democracy, not solely for American democracy, but the world as well, demonstrating that even healthy, long-lived democracies such as American democracy may not be immune to ideological threats. While there is a common belief among many scholars that democracy is experiencing a crisis, there is a lack of clarity over what kind of problem we are dealing with and whether this crisis is unique. In this thesis, more detailed and comprehensive analysis will be made of Poland's case because of its relevance to understanding the global phenomenon of democratic backsliding. Analysis of Polish democratic backsliding may add new insights to understanding the autocratization process.

However, it is essential to note that my approach to the study of Polish democratic backsliding follows institutional approaches in which institutional processes such as elections or other state organs are considered. At the same time, I will look more closely at the Polish political system's formation and transformation. Especially, it is significant to study the PiS party's discourse as it has influenced the current Polish political system and its democratization process. Therefore, in the following section, I will provide a brief explanation of the Polish political system.

\section{Polish Political System}

Poland has a Parliamentary Republic form of government where the President is the head of the state, and the prime minister is the head of the government. The Parliament is comprised of two houses: the lower (Sejm), which consists of 460 elected members, and the upper (Senate), with 100 elected members. Elected members of both houses serve for a four-year term. To explain the issue addressed in this thesis, it is significant to draw readers' attention to the necessary information concerning the main political parties in Poland. Since 1989, there have been eight democratic elections to the Polish Parliament, with six coalition governments 
and two single-party governments (1989 and 2015). In 1989, the Democratic Union (UD), which represented Solidarność (Solidarity), won the first election after the transformation, and it was the first party to form a government. All governments in the years from 1991 to 2015 have been based on coalitions. The PiS party won the elections in 2015 and formed a singleparty government. Since the PiS party controls the presidency and has majority in both houses, it is working to make judiciary reforms in the Constitutional Court, affecting Poland's entire structure.

Considering the classification of different parties, one can describe the following as leftwing parties: the UD, the UW, the SLD, and the PO, and right-wing parties: the Confederation of Independent Poland (KPN) and the Movement for the Reconstruction of Poland (ROP). Besides, taking into consideration the populist dimension, we can identify the Self-Defense (Samoobrona in Polish) as populist-leftist, and both the League of Polish Families (LPR) and PiS as populist-rightist (Hartlinski, 2019, 741).

The left-wing party Democratic Left Alliance (SLD) was registered as a party in 1999. The SDL is a post-communist group that held coalition governments in 1990-1999. Another left-wing party is Labour Union (UP), established in 1992. Although considered a left-wing party, its members mostly derive from the anti-communist opposition. Parties operating in the center of the political scene are the Democratic Union (UD), created in 1991 by Tadeusz Mazowiecki, and the Freedom Union(UW). The UW was formed in 1994 because of its merger with the Liberal Democratic Congress (KLD), which was headed by Donald Tusk. Because of the political scene's transformations, Donald Tusk left the UW in 2001 and formed the PO party with some ex-members of the UW party (Hartlinski, 2019, 739-741).

In the past, parties identified as the right-wing KPN, ROP, and LPR played a transitory role and never had broad social support, nor did they win seats in the Parliament. Significantly, the formation of PiS and its electoral victory in 2005 showed the strength of a right-wing party 
on the Polish political scene. Another party that warrants attention as an ally of PiS is the SelfDefense party, a populist party. The Self-Defense party was founded in 1999 under the leadership of Andrzej Lepper and concentrated its activity on challenging the political status quo and the elites behind it.

The other party that needs to be mentioned is the Polish Peasants' Party (PSL). Its members have held seats in the Sejm for the longest period, and it is a party that has appeal to the rural electorate. Therefore, PLS is capable of forming coalitions with both left and right-wing parties. Since its formation, it has joined coalition governments twice with SLD and twice with PO.

The Polish party system can be divided into two periods, with 2001 as the milestone, when both the Law and Justice (PiS) and the Civic Platform (PO) parties were founded, and entered the Parliament. Since then, these two parties have been playing a crucial role in Polish politics. The dissolution of the right-wing centered coalition in 2001: the Solidarity Electoral Action (in Polish: Akcja Wyborcza Solidarność, AWS) was among the main causes behind the emergence of new political parties on the Polish political scene (Hartlinski, 739). In addition, a politician who predominantly played a crucial role in the PiS party's foundation, Lech Kaczynski (at that time the Minister of Justice); and Donald Tusk (the Freedom Union, UW party member) were instrumental in the PO party creation. Since then, the two major parties have been on the Polish political scene: the Civic Platform (PO) and the Law and Justice (PiS).

The PO party was formed in 2001 under Andrej Olechowski and Maciej Płażyński as a liberal-conservative party. However, its orientation shifted to being a catch-all party with right and left wings in the course of time. The PO was a leading party in the government from 2007 to 2015 under the leadership of Donald Tusk. 
The Kaczyński twins, Lech and Jaroslaw, founded the PiS in the same year, 2001, as a centrist and Christian democratic party. The PiS party has been in power twice, leading the government from 2005 to 2007 and again from 2015 to the present (2021). The PiS party began as a center-right party, but it has shifted its ideology to a nationalist-conservative, Christian democratic, and populist political party in the following years. Currently, the PiS holds 237 seats in the Sejm (lower house), a simple majority, and 66 in the Senate. The PiS is the first party to form a single-party government since the fall of communism in 1989.

Table 1

Parties and Voting in Poland in 1991-2015

\begin{tabular}{|c|c|c|c|c|c|c|c|c|}
\hline $\begin{array}{l}\text { Elections to the } \\
\text { Sejm }\end{array}$ & 1991 & 1993 & 1997 & 2001 & 2005 & 2007 & 2011 & 2015 \\
\hline $\begin{array}{l}\text { Number of } \\
\text { formations in the } \\
\text { Sejm }\end{array}$ & 29 & 6 & 5 & 6 & 6 & 4 & 5 & 5 \\
\hline Winner & UD & $\begin{array}{l}\text { SLD } \\
\text { (coalition) }\end{array}$ & $\begin{array}{l}\text { AWS } \\
\text { (coalition) }\end{array}$ & $\begin{array}{l}\text { SLD + } \\
\text { UP }\end{array}$ & PiS & $\mathrm{PO}$ & $\mathrm{PO}$ & PiS \\
\hline $\begin{array}{l}\text { Government } \\
\text { coalition }\end{array}$ & 3 & $\begin{array}{l}\text { SLD + } \\
\text { PSL }\end{array}$ & $\begin{array}{l}\text { AWS + } \\
\text { UW }\end{array}$ & $\begin{array}{l}\text { SLD + UP } \\
+ \text { PSL }\end{array}$ & $\begin{array}{l}\text { PiS+ } \\
\text { S+ LPR }\end{array}$ & $\begin{array}{l}\mathrm{PO}+ \\
\mathrm{PSL}\end{array}$ & $\begin{array}{l}\mathrm{PO}+ \\
\mathrm{PSL}\end{array}$ & PiS \\
\hline $\begin{array}{l}\text { Left-wing or right- } \\
\text { wing government }\end{array}$ & Right & Left & Right & Left & Right & Center & Center & Right \\
\hline $\begin{array}{l}\text { Presidential } \\
\text { elections }\end{array}$ & 1990 & 1995 & 2000 & 2005 & 2010 & 2015 & & \\
\hline Referenda & 1996 & & 1997 & & 2003 & & 2015 & \\
\hline
\end{tabular}




\section{Theoretical Framework}

Existing literature has shown that various scholars, including Sadurski, Jankovic, Fomina, and Kucharczyk, aggregate constitutional changes, populism, and backsliding into a set of distinct propositions about the democratization process in Poland. While their analyses are nuanced and comprehensive, democratic backsliding analysis nevertheless suffers from a lack of conceptual synthesis building. Therefore, in this thesis, I will study five conceptual building blocks in relation to Poland's backsliding. They are backsliding, consolidation, populism, hybrid regimes, and elections. Bringing together five conceptual building blocs into one explanatory framework will help make a coherent frame of understanding democratic recession in Poland and perhaps other countries.

Five concepts are critical in explaining the state of democracy in Poland, particularly the reversal witnessed in the past decade. These are democratic consolidation, democratic backsliding, hybrid regime, populism, and elections.

\section{Democratic Consolidation}

The democratization process is considered to have three stages: opening, transition, and consolidation. The concept of 'democratic consolidation' is multidimensional. Many scholars, including Linz and Stepan (1996), have studied the theoretical and empirical problems of democratic consolidation. Linz and Stepan emphasize the importance of behaviors and attitudes in which "democracy as a complex system of institutions, rules, and patterned incentives and disincentives has become, in a phrase, the only game in town" (Linz \& Stepan, 1996, p. 5). In their elaboration of the consolidation process, they distinguish five requisites for consolidated democracy. They are civil society (freedom of association and communication), 
political society (free and fair electoral contests), the rule of law (constitutionalism), state apparatus (rational bureaucratic norms), and economic society (institutionalized market). In this framework, civil society, political society and rule of law are identified as pre-requisite and necessary conditions for a democratic regime's sustenance. The other two can serve to enhance consolidation.

Since countless scholars have studied democratic consolidation, the list of conditions for the consolidation has expanded to include such various requisites as the diffusion of democratic values, civilian supremacy over military, party pluralism, the protection of minority rights as well as neutralization of anti-system actors, the stabilization of electoral rules, decentralization of state powers, economic stabilization, judicial independence, and alleviation of poverty (Schedler, 1998, pp 91-92). Schedler states that democratic consolidation does not have to have one commonly shared meaning, but it can be interpreted and applied depending on the context and circumstances. For example, one can equate democratic consolidation with avoiding an authoritarian regression, whereas others can regard democratic consolidation as the same as democratic deepening and advancing the quality of democracy. Schedler states that:

"Those who are concerned with democratic stability and try to avoid regressions to either nondemocratic or semi-democratic regimes support 'negative' notions of democratic consolidation, while those who are concerned with democratic advances and try to attain progress toward either liberal or high-quality democracy sponsor 'positive' notions of democratic consolidation" (1998, pp94-95).

Despite mutual recognition of different notions of democratic consolidation, it can always change in application because of alternative concepts, interpretations, and contexts. Therefore, according to Schedler, the definition of democratic consolidation should be restricted to only one criterion, which is referred as "a democratic regime that relevant observers expect to last 
well into the future and nothing else" (Schedler, 1998, p 103). Suppose we associate democratic consolidation with completion of democracy, democratic deepening or avoiding democratic breakdown. In that case, we get requisites of democratic consolidation that are so open and multidimensional that no democracy will ever be considered as 'fully consolidated' (Schedler, 1998, p 104).

\section{Democratic Backsliding}

The democratization process can go different ways in different countries. Some can progress towards democracy, some can remain in a grey zone, and some can reverse from democratization towards autocratization. The term itself, 'backsliding,' refers to the slowing down or reversal of a trajectory towards de-democratization. Backsliding is a result of political struggle made possible by shifting balances of power. Backsliding deteriorates the quality of democratic governance. Quality, combined with competitive electoral procedures, civil and political liberties, and government accountability will decline.

Executive leaders unconstrained by state institutions are left free to initiate democratic backsliding by attacking existing institutions' accountability, hence their efficaciousness. Recent increases in terrorist attacks and the refugee crisis may substantially push the political culture towards weakened toleration and provide the rationale for popular leaders. Additionally, popular leaders who praise or collaborate with authoritarian leaders undermine the democratic system of rule.

Backsliding can lead to autocratization. Autocratization is a process by which the number of countries undergoing democratization declines, while at the same time, autocratization affects more and more countries (Luhrmann \& Lindberg, 2014, p. 8). To understand the autocratization process, we must study democratization. Like waves of democratization, the 
third wave of autocratization created 75 episodes of reverse effects (Luhrmann and Lindberg 2019, p. 9) and has mainly affected democracies, unlike prior waves. This phenomenon is especially concerning because autocratizers are using legal and gradual strategies to undermine democracies. For example, democratic consolidation was reversed by Hungarian Prime Minister Viktor Orban, who came to power by legal means and implemented gradual political system changes. Poland under PiS leadership is facing the same fate as Hungary, where the PiS party has introduced many incremental changes to freedom of media, and changes in the judicial branch, which has led to the consolidation of power in the executive branch, undermining democracy.

Often backsliding occurs through a series of incremental changes in the rules and informal procedures that form elections, rights, and accountability. For example, a political actor in an office may initiate a low-level assault on democratic accountability and thereby subvert democracy from within, as is happening in Poland under the leadership of the PiS government. Because of loosened constraints of accountability, norms, and officials' obligation to answerability and punishment in front of citizens or governing agencies will be weakened and this can result in corruption and highly polarized politics. Additionally, backsliding makes elections less competitive, without entirely undermining the electoral mechanism. One of the main features of democracy, the uncertainty of election results, will erode. Low accountability and less competitive elections will lead to declining public participation in political decisionmaking.

\section{Hybrid Regimes}

By the end of the third-wave democratization, approximately 100 countries were considered as some kind of democracy (Diamond, 2002). However, a closer analysis of this 
transition paradigm revealed that many of the states were stuck in the 'grey zone' between liberal democracies on the one hand and closed authoritarianism on the other (Mufti, 2018). Ultimately, an abundance of diminished subtypes of democracy and authoritarianism, as well as a lack of common perception in terms of definition among scholars, has posed conceptual challenges on how to classify these grey-zone countries. So far, no agreement has been reached among political science scholars on whether to call these countries 'hybrid' (Mufti, 2018), 'mixed' (Cassani, 2014), 'defective democracies' (Bogaards, 2009), or 'competitive authoritarianism' (Levitsky \& Way, 2010).

By the 2000s, many countries had adopted a form of electoral democracy with regular, competitive, and multi-party elections. Yet, they failed to meet substantive attributes of democracy, such as horizontal accountability, the rule of law, and effective governing institutions. These countries were characterized as 'hybrid,' with a mixture of institutional traits typical of democratic and authoritarian regimes. Hybrid regimes were not a new political phenomenon, and they existed even before the third wave. What has been crucial about this political phenomenon is an increase in the number of hybrid regimes at the end of the Cold War (Cassani, 2014, p. 550).

The boundary between defective democracy and authoritarianism is often so blurred that it is hard to differentiate them. Thus, many scholars came to name grey zone countries as 'hybrid,' a mixed type of regime dissimilar to other governments (Riaz, 2019). Initially, the adaptation of constitutionalism and multi-party elections led scholars to believe that they are in a transition period and are likely to become a democracy. However, a decade of scholarship showed that the institutions and electoral procedures were facades (Riaz, 2019, pp. 14-15). They were a mixture of democratic and authoritarian institutions, where coexistence and interaction of institutions profoundly shaped politics. The introduction of formally democratic institutions often provided essential assistance in promoting the political survival of 
authoritarian rulers. Also, the institutionalization of a hybrid regime represents an instrument of consolidation for the regime. Consequently, a hybrid regime will become resistant to any threats raised by opposition. Even after a leader or government changes, the regime's practices will remain. Dictators may take advantage of democratic procedures to gain legitimacy.

This political regime model requires careful and nuanced judgments about the scale, pattern, and context of functioning violations. Because of the difference of institutions in many developing countries, they are different from classical authoritarianism. Thus, they cannot be called either authoritarianism or a democracy. Bogaards writes:

"Hybrid regimes are neither a subtype of autocracies nor of democracies but a regime type on their own, encompassing those political systems that on plausible grounds cannot be classified as either autocracy or democracy" (Bogaards, 2002, p. 415).

Moreover, hybrid regimes should not be considered regimes in transition, since regime in transition is changing from one type to another. A hybrid regime is itself some type of regime. After the third wave of democratization, an increasing number of countries adopted democratic institutions and held regular multi-party elections. However, these elections are often manipulated, and opposition parties are subject to some form of repression. Take, for example, Russia. There is a multi-party election with opposition parties and independent media, and some political space is allowed. However, these elections are manipulated, the opposition faces systematic repression, and media outlets are threatened by the government. Analysis of the level of the hybridity and political violations and conceptualization of hybrid regimes assist in evaluating the future of the administration. It also makes clear what precautions should be taken to establish a democracy. 
To sum up, after two decades of scholarly research on hybrid regimes and their nature, the following conclusions can be drawn. First, hybrid regimes are not diminished subtypes of democracy or authoritarianism; they constitute a new kind of regime. Secondly, hybrid regimes are not in a transitional paradigm (Bogaards, 2002, p. 415). In other words, the adaptation of democratic institutions in a country does not necessarily mean it is amending itself and becoming a democracy. Many third-wave democracies are apparent examples of this political phenomenon. Thirdly, hybrid regimes prove to be more durable than many scholars had expected. Many scholars believe that hybrid regimes are the most fragile form of nondemocracy and will likely either fail or become democratic (Cassani, 2014, p. 551). However, hybrid regimes appear to be the most durable regime type and are at less risk of a breakdown than one party or military regimes. Finally, hybrid regimes can be contagious in regions, and many power-seeking leaders may adopt this kind of regime, imitating other regional examples to gain national legitimacy. The support of Orban's government for the PiS policies against the European Union sanctions is a good example.

\section{Populism}

Mudde and Kaltwasser define populism as "a thin-centered ideology that considers society to be ultimately separated into two homogeneous and antagonistic camps, the pure people versus the corrupt elite, and argues that politics should be an expression of the general will of the people" (Mudde \& Kaltwasser, 2017, p. 6).

In the context of liberal democracy, Mudde and Kaltwasser insist that populism works as either a threat or a corrective for democracy, depending on its electoral power and the context in which it arises. However, before discussing populism in terms of democracy, it is crucial to distinguish traditional democracy from liberal democracy. Traditional democracy is defined as 
the combination of popular sovereignty and majority rule, alluding to the idea of selfgovernment where rulers are selected in competitive elections by majority rule. Liberal democracy, on the other hand, respects not only popular sovereignty and majority rule, but also creates independent institutions specialized in the protection of fundamental rights such as freedom of expression and the security of minority rights policy, which are absent in traditional democracy. Today, many populist leaders criticize these independent institutions by claiming that protecting the people's will and dismissing minority rights that are inherent to the liberal democratic model. This strategy allows populism to undermine independent institutions' legitimacy and deteriorate the democratization process. In extreme cases, it can even lead to the backlash of the democratization process by giving the executive branch enough power to alter the regime to a more authoritarian regime, as happened in Peru and Venezuela (Mudde \& Kaltwasser, 2017).

In general, populism is more antithetical to democracy in terms of public contestation and more favorable in terms of political participation. Therefore, it is neither inherently bad nor good for democracy. Thus, the question of how populism can assist in a democratization process can be answered depending on the context of the leadership and what approach is employed. According to Mudde and Kaltwasser, populism can be conceived as a discourse, an ideology, or a worldview that is able to alter a political system to democracy or backslide a political system to a more authoritarian regime. Although populism can challenge democratization, the scope of its influence can depend on the political power of populist forces and the type of political system.

In this study to determine whether the tactics of the PiS party were, indeed, populist, among the following checklist of contemporary populism's sources of appeal:

1) The sense of economic insecurity with a resultant loss of social cohesion 
2) Xenophobic attitudes toward others, especially migrants and refugees

3) Resentment towards globalization and internationalism, and a renewed support of nationalism

4) Cultural and religious resentment, expressed in a distrust of political correctness and multicultural tolerance

5) Disenchantment with current political elites and with the establishment, combined with the perception that the establishment is arrogant, remote, and insensitive to the needs of real people

6) Impatience with liberal constraints on government, with checks and balances viewed as an institutional obstacle to getting things done and to the will of the people (Sadurski, 2019).

Only three tactics of populism were observed in the PiS party's discourses and therefore, I will look at only three tactics of populism in relation to Poland. They are:

1) Xenophobic attitudes toward others, especially migrants and refugees

2) Disenchantment with current political elites and with the establishment, combined with the perception that the current establishment is arrogant, remote, and insensitive to the needs of real people

3) Impatience with liberal constraints on government, with checks and balances viewed as an institutional obstacle to getting things done and to the will of the people.

\section{Elections}

In competitive authoritarian regimes, elections fall in between free, fair, and repressive massive-fraud extremes. On the one hand, elections are competitive, and opposition parties are allowed to campaign publicly, although these elections are often not free and are manipulated. 
On the other hand, despite allowing opposition, candidates and opposition supporters can be intimidated or allowed only limited finance and media access. An example is the 2018 presidential election in Russia. New regulations for running for the presidency were introduced prior to the election. Based on the new rules, opposition candidate Aleksey Navalni was considered ineligible to run for the Presidency. Exclusion of opposition candidates is another tactic many authoritarian leaders have been utilizing.

In established democracies, on the other hand, elections are free and fair, in the sense that there is no fraud or intimidation; opposition candidates are not denied access to the media or finance, nor are they subject to repression or harassment. Electoral procedures are carried out under established regulations, which are not biased or manipulated (Levitsky \&Way, 2010). Elections in France, Norway, Finland, and other consolidated democracies are cases in point.

However, in many third-wave democracies, elections are used as a tool to decimate democracy, rather than to consolidate it. Even in established democracies, electoral procedures have become controversial because of the rise in populist leaders' number who utilize elections to seek popular support and legitimacy for their authoritarian tendencies. Since the end of the Cold War, many populist leaders have been using a mixture of economic performance, nationalism, and ideology to build a robust legitimizing basis. In these countries, state institutions are used for this purpose. They primarily rely on 'social contract' ${ }^{8}$ and attempt to use 'diffuse ${ }^{9}$ and 'specific support' ${ }^{10}$ tactics to gain legitimacy and create schisms within the society. China's ruling Communist Party (CP), for example, was very successful in gaining

\footnotetext{
${ }^{8} \mathrm{~A}$ reciprocal relationship that guaranteed political acquiescence in return for relatively acceptable economic performances (Johannes Gerschewski, 2013).

${ }^{9}$ Diffuse support refers to what the regime actually is or represents. In contrast to specific support, it is more general and long-term oriented. Diffuse support of this nature can stem from both the political ideologies that have been the main focus in classic totalitarian research, and also from religious, nationalistic, or traditional claims, from the charisma of autocratic leaders as well as from external threats that lead to domestic rallyaround-the-flag effects (Gerschewski 2013, p, 20).

${ }^{10}$ Specific support can be defined as the quid pro quo for the fulfilment of demands, and particularly includes the performance orientation. The better the government performs economically, socially, and in terms of public order, the more legitimate it is in the eyes of the ruled.
} 
public legitimacy through such indoctrination mechanisms. Today these mechanisms have been widely used by populist leaders. They are considered to pose a threat even in consolidated or consolidating democracies, particularly due to perceived external threats, such as an influx of refugees and global economic and environmental crises.

\section{Methodology}

This thesis explores the democratization progress that was made in Poland between 1989 and 2015 and the gradual democratic backsliding since 2015, using data from existing sources. To assess Poland's democratic backsliding following data from Freedom House, The Economist Intelligence report, IV Polity indicators on democracy will be used. I will also analyze the rhetoric, speeches, and statements of various political parties, especially of PiS, to see whether there is any relationship between the populist postures and the actions of the PiS contributing to democratic backsliding. In this thesis, I intend to examine the relationship between democratic recession and populism. An analysis of campaign strategies used by the PiS party shows that democratic recession and the rise of populism are closely tied to the specific conditions (e.g., refugee crisis) and the time framework faced by Polish democracy. In other words, the decline in civil liberties, and the political rights in the aftermath of the 2015 elections, illustrate that actions taken by the PiS party contributed to the reversal of the democratization progress. In this context, to identify the relationship between democratic backsliding and the rise of populism in Poland, the discourse mechanism, election manifestos, and party speeches used by the PiS party during the election campaign will be examined.

To assess the progress of democratization in Poland, analogous ratings for political rights and civil liberties from Freedom House in the time-period from 2005 until 2020 will be examined. The Freedom House assessment of political rights is divided into seven 
subcategories: 1) Electoral Process, (EP) 2) National Democratic Governance (NDG), 3) Civil Society (CS), 4) Independent Media (IM), 5) Local Democratic Governance (LDG), 6) Judicial Framework and Independence (JFI), and 7) Corruption (CO). The Polity IV data set is based on the evaluation of elections for competitiveness and openness, the nature of political participation, and the degree of checks on executive authority can tell us the state's level of democracy.

This thesis will also discuss particular constitutional changes such as the amendment of the Law on 19 November, 2015, in respect of the Constitutional Tribunal, which inter alia enabled the dismissal of the previously appointed judges (Jankovic, 2016, pp 52-53) and laws, for example, the new Police Act, which restrict civil freedoms through monitoring the Internet (p. 58) and their impact on civil and political rights and institutions, to show how democracy is backsliding under the leadership of PiS government.

This thesis is divided into five chapters. The second chapter will discuss the available literature on Poland's democratization process. In the second chapter I will offer contrasting thoughts on Poland's backsliding case and how scholars define current political system in the country. The third chapter will examine the history of Poland, particularly the history of the democratization process from 1989 until 2015. In this chapter I will show the changes in the trajectory, drawing on the data from various sources mentioned previously. The fourth chapter will have two sections: the first section will discuss how various institutional measures such as constitutional changes have impacted the politics and governance. The second section will analyze the discourse and political positions of the Law and Justice (PiS) party to mobilize popular support before and after the election of 2015. The chapter will focus mainly on the events from 2015 onwards. The final chapter will summarize the discussion by reiterating the main points, highlighting the research contributions and offering a few suggestions for future studies. 


\section{CHAPTER II: HOW TO DEFINE THE CURRENT REGIME IN POLAND?}

Various scholars identify Poland under different categories, and they express contrasting opinions about Poland's backsliding. Therefore, in this chapter, I first discuss mainstream scholarship explanations on Poland's backsliding. I will then explain why I define the current Polish regime as a hybrid regime, and lastly, I will offer analysis on the discourse of the PiS party. The vast majority of hybrid regimes do not present enough democratic characteristics to be classified as a democracy. Therefore, I study Poland under PiS government as a form of hybrid regime, because PiS party has essentially illiberal and even authoritarian traits. The PiS government blends both democratic and authoritarian principles. In many ways and many classifications, Poland is still regarded as a democratic polity. Yet recent institutional changes reveal its hybrid nature where institutions representing democratic principles have been converted into government tools.

In this study of democratic backsliding in Poland, most of my attention is centered on the rise of right-wing populism in the country, which brought success for the PiS party. I argue that the PiS party owes its success because it managed to stimulate contemporary populism's sources of appeal skillfully.

\section{Explanation in Mainstream Literature}

According to Wojciech Sadurski ${ }^{11}$, Andrej Duda's Law and Justice (PiS) party, elected to power in 2015, reversed Poland's democratization process by making many significant incremental changes to the freedom of media, and changes in the judicial branch, leading to a consolidation of power in the executive branch and undermining democracy. Sadurski

\footnotetext{
${ }^{11}$ Wojciech Sadurski is Jurisprudence professor at the University of Sydney School of Law.
} 
describes the Polish backsliding phenomenon as an 'anti-constitutional populist backsliding' (Sadurski, 2019, 113) in which each of the concepts captures an important phase of Polish democratic regression. The Polish constitution establishes that the central institutions of power are the President and the Prime Minister. However, according to Sadurski, power is currently centered in one person, Jaroslaw Kaczynski, a leader of the PiS party, who is commanding the country without constitutional responsibility and accountability. Sadurski writes:

"The paramount role of Kaczynski in the Polish political system, though totally invisible to the constitutional design, has been accepted and recognized as such, also by foreign journalists or politicians, who seek meetings with him in precedence to meeting the Prime Minister or the President, knowing that this is where the true power resides" (114).

Fomina and Kucharczyk, (2016), on the other hand, liken the PiS party government to the global phenomenon described as a "contemporary authoritarian populism" by Pippa Norris (58). According to Fomina and Kucharczyk, the discourse of the PiS party is defined as "a general protest against the checks and balances introduced to prevent people's direct rule" (Fomina \& Kucharczyk, 2016, 58), which emphasizes PiS's role in state security, civil diversity, and traditional values. The PiS victory is 'a cultural backlash' 12 against ongoing social changes brought by the collapse of communism in 1989 and EU membership in 2004. PiS's strong stance on national identity, sovereignty, and respect for the Catholic Church ensured popular support for its unprecedented polarization and xenophobic ideology. Fomina and Kucharczyk write:

“Kaczynski's victory would not have been possible without the creation of a highly effective 'anger industry,' which fed on the many discontents of different

\footnotetext{
12 While most Poles remain at least formally Roman Catholic, studies show growing social and political splits over moral and cultural issues rather than socioeconomic issues.
} 
social groups and pushed the 'Poland in ruins' narrative despite considerable evidence to the contrary" (Fomina \& Kucharczyk, 2016, 66).

According to Tworzecki, Poland's backsliding began because of asymmetric polarization at the elite level, meaning that the discourse of the PiS party broke from liberal democratic consensus and employed extreme polarization at the electorate level (Tworzecki, 2019, 100). Tworzceski (2019) describes the PiS party as a 'charismatic party,' stating:

“PiS was not so much an 'organization' (a term that implies a degree of institutionalization or depersonalization), but rather the private domain of its chairman, a type that some literature refers to as a 'personal party' —one held together only by the founder's authority" (102).

Tworzecki is among the few scholars who point out the extraordinary aspect of the decision-making power exercised not by the president or prime minister, but by Jaroslaw Kaczynski, the founder of the PiS party, routinely referred by his colleagues as 'Naczelnik' (leader) (Tworzecki, 2019, 99). Indeed, the Polish case stands out from other cases in the sense that democratic consolidation stagnated not because of the official office-holding figure, but because of a person who does not hold any significant decision-making position in the country and is only a member of the party. Thus, analysis of the role of Jaroslaw Kaczynski in Polish politics should be made.

Wojciech Przybylski argues that the 2010 Smolensk plane crash, which killed all 96 high ranking members of the government, including sitting president Lech Kaczynski (Jaroslaw Kaczynski's twin brother), was a turning point for PiS political ideology. Since the crash, Jaroslaw Kaczynski has successfully reshaped the party's political strategy, incorporating new conspiracy theories of the plane crash and hence investigation results that served as a cornerstone belief uniting the party's hardcore supporters. As an example, while at the time of 
the crash 2010 PiS party supporters comprised 25 percent of the voters, in 2015 the number of supporters increased to 37.6 percent (Przybylski, 2018, 56)

Additionally, during the electoral campaign, the PiS party introduced new discourses, hiding its most radical politicians from the public eye and reconstructing the image of the party as a moderate party. Przybylski states that despite the PiS party's conspiracy theories about the involvement of Russia in the plane crash and Kaczynski's animosity for the Russian government, the PiS party policy changes resemble the previous communist regime, a model of centralized power with rigid political control from the top and limited decision-making at the local level (Przybylski, 2018, 56). Thus, Przybylski explains the backsliding in Poland based on Poland's historical trajectories saying:

"Decades of Soviet propaganda have had a lingering impact, weakening democratic principles in a way that continues to affect the social fabric of these post-communist countries. Even where educational systems have been reformed, the danger of prejudice arising in connection with national historical experience remains" (Przybylski, 2018, 61).

While many political science scholars argue that the PiS party undermines the rule of law and jeopardizes the fundamental principles of liberal democracy and human rights, Sava Jankovich argues that the PiS party has not so far blatantly breached the law. Although Jankovich admits that the PiS party's new policies are threatening the democratization process, the party is still working within the limit enabled by the nature of the Polish political system (60). According to Jankovich, the nature of the Polish Constitution is susceptible to manipulation by the legislature, executive and the judiciary branches, and therefore any changes carried out by the ruling political party should not be blamed on the PiS party. Jankovich says: 
"The law-making, and in a broader sense the ruling capacities of the Law and Justice party that it owes exclusively to the construction of the Polish political system, cannot therefore be equated with an accusation of violation of law" (62)

Jankovich notes that while Polish democratic backsliding has attracted a great deal of criticism, there is a lack of coherent analysis, which explains the differentiation between who rules and how they rule. In other words, the nature of the Polish political system enables the PiS party to dominate all the institutions responsible for the legislative process, and thus their policies have been carried out within the limits of the law. Therefore, the issue of the Constitutional Tribunal judges was a consequence of constitutional design, not by the current party.

One of the main challenges of identifying the scale of violations in defective democracies is that there is no consensus or coherent guideline that agrees on the definition of defective democracies. Polish democratic backsliding is not an exception to this challenge. While many scholars acknowledge that the violations committed under PiS party governance are undemocratic, nonetheless there are varying opinions on how to define the current Polish regime. In this regard, in the following section I will look at the case of Poland as a Defective democracy.

\section{The Case of Poland as a Hybrid Regime}

One of the main challenges of identifying the scale of violations in hybrid regimes is that there is no consensus or coherent guideline that agrees on the definition of hybrid regimes. Polish democratic backsliding is not an exception to this challenge. While many scholars acknowledge that the violations committed under the PiS party governance are undemocratic, nonetheless there are varying opinions on how to define the current Polish regime. In this 
regard, many political science scholars, including Sadurski, Fomina, Kucharczyk, and Tworzecki, identify Poland as 'an illiberal democracy' because of its weakened institutional checks and balances, changes to the judicial system, and changes introduced to the freedom of media under the PiS government.

Fareed Zakaria first introduced the concept of an 'illiberal democracy' (1997, p. 23). He describes it as a gradual erosion of democracy by elected officials. More specifically, an illiberal democracy may show some fairness in the first cycle of elections where free and fair elections allow illiberal leaders to win and act within their constitutional mandate. However, in the end, these same illiberal leaders curb the institutions responsible for the protection of democracy (Sadurski, 2019, p. 243). Because of the constitutional changes, democracy becomes merely formal and loses its self-protection and self-correction aspects.

Sadurski argues that horizontal accountability, a network of autonomous powers such as other institutions that can challenge the responsibilities of elected officials, is currently missing in Poland (Sadurski, 2019, p. 242). The PiS utilizes the majoritarian legitimacy discourse on the basis of its claim to represent the will of the nation, and those who oppose party policies are simply excluded. As an example, because PiS party members are strongly religious, and practicing Catholic Christians, condemn LGBT rights or women's reproductive rights, the party policies undermine those minority rights and do not capture the interests represented by minority groups. Sadurski (2019) writes:

"The PiS assaults on some par excellence democratic rights and procedures imply that illiberal democracy, Polish style, has a strong anti-democratic tendency built into it" (243).

Tworzecki goes further, calling the political nature of the PiS an authoritarian system that effectively delegitimized existing institutions, sowed mistrust among Poles by normalizing 
conspiracy theories, and flooded the news outlets with false information (2019, p. 103). Through a number of effective polarization techniques, especially in the sense of negative sentiments where voters are exposed to the negative aspects of immigration, and economic circumstances, rather than positive narrative of immigration and economic growth, the PiS managed to attract a large number of voters. Tworzecki (2019) concludes that increasingly effective discourses of the PiS party to create us versus them politics leads partisan supporters to tolerate illiberal behavior by their own (PiS) party and thus turn blind eyes to the erosion of democratic norms in the country (Tworzecki, 2019, p. 106).

Przybylski (2018) notes that in order to defend new changes brought by the PiS government in the legislative and administrative bodies, PiS party members introduced a narrative of 'sovereign democracy' (Przybylski, 2018, p. 59). The term of 'sovereign democracy' was first introduced by Vladislav Surkov $^{13}$ to legitimize the illiberal political system of the Russian government. The narrative of sovereign democracy would create democratic window dressing for the PiS party's illiberal slides since the PiS won the majority of seats in Parliament, claiming to represent the sovereign will of Poland. Nevertheless, Przybylski (2019) argues that we should avoid hasty generalizations and look at issue areas separately. Przybylski (2019) rejects the use of terms such as 'defective democracy,' 'illiberal democracy,' or 'sovereign democracy' because he still considers Poland a democracy.

In The Economist Intelligence Report (2020), Poland is defined as a 'flawed democracy', while in the Freedom House Report (2019), Poland is identified as a semiconsolidated democracy'. Although the terms 'flawed' and 'semi-consolidated' ${ }^{14}$ democracies are often used interchangeably in regards to Poland's regression, in this thesis, I place Poland

\footnotetext{
${ }^{13}$ Vladislav Surkov is a close aide to Russia's President Vladimir Putin.

14 "Countries receiving this score are electoral democracies that meet relatively high standards for the selection of national leaders but exhibit weaknesses in their defense of political rights and civil liberties" (Csaky, 2020, p. 25).
} 
in the category of hybrid regimes because of crucial changes and irregularities in the Judiciary and the CT. In other words, according to The Economist Intelligence Unit Report flawed democracies:

"Have free and fair elections, even if there are problems (such as infringements on media freedom), basic civil liberties are respected. However, there are significant weaknesses in other aspects of democracy, including problems in governance, an underdeveloped political culture, and low levels of political participation" (EIU, 2019, p. 55).

And hybrid regimes:

"Elections have substantial irregularities that often prevent them from being both free and fair. Government pressure on opposition parties and candidates may be common. Serious weaknesses are more prevalent than in flawed democracies - in political culture, the functioning of government, and political participation. Corruption tends to be widespread, and the rule of law is weak. Civil society is weak. Typically, there is harassment of and pressure on journalists, and judiciary is not independent” (EIU, 2019, p. 55).

Many scholars, including Diamond, Levitsky, Way, Bogaards, Cassani, Schedler, Zakaria, and Riaz, have studied hybrid regimes and attempted to identify the boundaries between democracy and authoritarianism. A full functioning democracy is assessed in light of four dimensions: vertical legitimacy and horizontal accountability, along with the rule of law and effective government. However, if a regime has fully functioning democratic electoral procedures, and if other components such as repression of political rights (horizontal accountability) and irregularities in independent courts are present (vertical legitimacy), it is considered a hybrid regime (Bogaards, 2002, p. 403). Initially, the forms and dynamics of PiS's 
government were depicted as a flawed democracy. However, the systematic, targeted, and aggressive nature of the government's attacks on judicial independence further aggregated to the country's waning democracy. The PiS party has systematically curtailed the opposition's ability to play a role in the Parliament by forcing the adoption of laws via the urgent procedure, introduced several laws that limit freedom of the media and civil liberties. All of these weaken democratic institutions and provide the populist party, the PiS, with tools and incentives to overstay their time in power.

\section{The discourse of the PiS party}

According to Sadurski (2018), in Poland, the PiS party's electoral success and its appeal to a significant segment of the Polish electorate are due to combination of three effective strategies. They are:

1) Xenophobic attitudes toward others, especially migrants and refugees;

2) Disenchantment with current political elites and with the establishment, combined with the perception that the current establishment is arrogant, remote, and insensitive to the needs of real people;

3) Impatience with liberal constraints on government, with checks and balances viewed as an institutional obstacle to getting things done and to the will of the people (pp. 164166).

In the wake of the refugee crisis, xenophobic attitudes were skillfully stimulated by PiS in religiously homogeneous Poland. Uncovering corruption scandals ${ }^{15}$ about President

\footnotetext{
${ }^{15}$ In 2013-2014 the officials of PO party were secretly recorded in Warsaw restaurants discussing private deals and promotions. The leaks revealed top officials conspiracy efforts prior the 2015 election. For example, in the secretly recorded tape then Interior Minister Bartlomiej Sienkiewicz appeared to ask the country's central bank chief to give the economy a boost to help the government get re-elected. In another tape Polish Foreign
} 
Komorowski and his PO party incited anti-establishment sentiments in 2015. As an institutional obstacle to getting things done, PiS leaders who called for necessary and desirable reforms criticized legal and constitutional norms. A combination of all these three forms of populist discourse mechanisms brought the PiS party a victory.

Another strikingly effective strategy of the PiS was that during the electoral campaign, the PiS party not only excluded immigrants, but also discursively created 'ordinary' Poles visà-vis those who were not seen as 'real' Poles. Sadurski writes that the exclusionary, antipluralist, and anti-establishment nature of the PiS party skillfully employed simultaneously both xenophobic and anti-establishment discourses that targeted both immigrants and elites (Sadurski, 2019, pp. 246-247).

Once in office, the PiS introduced new laws that put constraints on democratic rights such as freedom of assembly and the media, strategically delegitimized opposition by unabashed pro-government propaganda in public media, and effectively politicized the institutions that manage the electoral process. With the PiS party governing both the presidency and the parliament, the opposition is suffocated, pluralism in the media is lost, and accountability as well as subjection of the government to effective constitutional constrains are undermined (Sadurski, 2019, p. 248).

Such an analysis shows that the transformation of Poland's political system is taking place without an outright destruction of democratic institutions. No visible revolutionary rhetoric is employed by the party, but rather a gradual capturing of one institution after another by officials loyal to PiS, especially to its leader Jaroslaw Kaczynski, and creating a clientelist

Minister Radoslaw Sikorski was quoted saying "We are suckers, total suckers. The problem in Poland is that we have shallow pride and low self-esteem" (BBC 2014) 
system in Poland. The current situation in Poland is best explained by Sadurski (2019), who describes it as:

Polish institutions are not being dismantled or destroyed or demolished, but are instead being hollowed out, eroded, and emptied: their sense and meaning which confer value on them, are all but lost, but their shells remain. For a spectator this creates the illusion of business as usual, while in fact the institutions have been thoroughly colonized by the governing body (249).

Research shows ${ }^{16}$ that initially the PiS party was able to mobilize its core supporters by promoting conspiracy theories about the politics of a parallel reality in which Jaroslaw Kaczynski blamed Russian as well as Polish secret services for the plane crash in 2010 and used the investigation results as a distraction from reality. Later during the electoral campaign, the PiS successfully rebranded its image, hiding signs of authoritarian leanings as well as extreme radical personalities (including Jaroslaw Kaczynski himself) from the public eye. Additionally, the PiS party flooded the news media outlets with false information and gained support of the young and well educated of the right (Fomina and Kucharczyk, 2016, pp. 6061). Consequently, all the discursive strategies of the PiS resulted in the growth of the number of PiS supporters. For example, while in 2010 the PiS party scored 25 percent of the voters, in 2015 the number of supporters increased by 12.6 percent, making it 37.6 percent (Przybylski, 2018, p. 56).

One vital element of hybrid regimes is considered an election procedure where dictators have the ability to change the regime towards a more authoritarian one and yet gain legitimacy. In addition, the electoral structure in Poland also allowed the PiS to form a single party rather

\footnotetext{
${ }^{16}$ For more see Claudia-Yvette Matthes (2016) “The State of Democracy in Poland after 2007. Analyzing the linkage between economic development and political participation"

16 "PiS's new election slogan. Kaczyński's party will convince voters with it?"
} 
than a coalition government. For example, in Poland, the PiS party received 38 percent of the votes in the 2015 parliamentary election and the rest of the votes given to other parties were wasted because of the inability of small parties to form a coalition government. This victory allowed the PiS party to form a government independently, without the need for a coalition government.

Tworzecki (2019) explains that the parliamentary system and a proportional electoral law should have discouraged the centralization of power, which often happens in presidentialism. In addition, Poland's constitution characterizes an effective set of checks and balances, with the Constitutional Tribunal domestically and European Union membership, which are constraints against the power of raw majoritarianism (Tworzecki, 2019, pp. 98-99). Despite a comprehensive set of checks and balance, a parliamentary electoral system allowed the PiS party to form an independent government with only 38 percent of the votes. The inability of smaller parties to come to terms with one another to form a coalition resulted in 15 percent of votes being wasted and the ultimate success of Kaczynski, who benefited largely from the absence of strong opposition in the parliament. This is a defect of the parliamentary/majoritarian system, notes Sadurski (2018, p. 166). It is well known that the majority of populist/authoritarian/anti-democratic leaders may prevent a change in political power structure, which is the major definitional criterion of democracy, by manipulating an electoral competition mechanism. The Polish case is no exception, because once the PiS came to power, in $2017 \mathrm{PiS}$ implemented a massive change to the electoral law, introducing enhanced control by both the parliamentary and the executive over the procedures of elections by introducing a new model, the National Electoral Commission (Polish acronym: PKW) (Sadurski, 2018, p. 159). Sadurski notes that the PiS party offered no serious explanation for the need to change the electoral law. The new electoral law allows the PiS party to change cadres and restructure electoral procedure. This, in turn, leads to entrenching the hegemony of 
the ruling party and denying fair chances to the opposition during elections (Sadurski, 2018, p. 158). 


\section{CHAPTER III: THE PATH TO DEMOCRACY: POLAND 1989-2015}

In this chapter, I aim to show the developments of democratization after the 1989 events. To understand Poland's democratic backsliding, it is crucial to learn about its path towards democratization. Poland was a communist country ruled by the Soviet Union until 7 April 1989, when the Roundtable Agreement was reached. By the late 1980s, it was clear that the communist party was losing national support and had to cooperate with the opposition to reach its goals. The communist party and the opposition needed each other to tackle the economic hardships Poland was facing at that time. The ruling party had found itself unable to reform the economy of Poland without the support of the opposition, while the opposition, Solidarity, was not officially legalized and was too weak to confront the communist government on its own (Castle \& Taras, 2002, p. 63). Hence, in February 1989, talks began between the communist leadership and the opposition, Solidarity. The talks were initially supposed to lead to the opposition's support of the communist regime's economic policies in exchange for the official recognition of Solidarity as an organization that could operate in the country legitimately. However, the negotiations on both sides did not end with the recognition of Solidarity. Once the legal status of Solidarity was confirmed, the opposition pushed for a bargain that would enable the trade union to participate in the political life of Poland (Howard \& Brzezinski, 1998, $\mathrm{p} 135)$.

\section{The Roundtable Agreement}

The Roundtable Agreement achieved a consensus by April 7, 1989, and the 1952 Constitution was amended to create space for political opposition to exist in Polish political life. It was the first and most important achievement of Solidarity on the path to changing the 
regime while maintaining political order and peace in Poland. According to the Roundtable Agreement, the Sejm officially removed the ban placed on the Solidarity movement and legalized the status of trade unions. Following this, the amended Constitution included a passage of a new electoral law that ensured political pluralism and independence for all political parties. This amendment marked the end of the authoritarian regime in Poland.

Secondly, during the negotiations it was agreed that the Sejm's unicameral system would be dissolved and a bicameral system would be created through new elections scheduled for June 1989. Following this agreement, the 'upper' house of Parliament, the Senate, which was abolished by the communists in 1951, was restored. According to the agreement, the Senate would have considerable legislative powers such as legislative initiative, the right to veto or amend Sejm legislation, and the ability to override laws with a two-thirds majority (Howard \& Brzezinski, 1998, p 136). The Senate would comprise of 100 members freely elected, and the reintroduction of bicameral system ended the monopoly of the communist party, which controlled Sejm. This meant that all the laws introduced by the communist or Sejm would now be scrutinized and checked within the legislative branch, the Senate. This was a step towards dismantling the monopoly of the communist party in the country by the Solidarity. This initiated checks and balances of power in Poland that led to gradual liberalization and democratization in the country.

Additionally, the pre-existing electoral system, which only allowed the Communist party, was abandoned, reserving 65 percent of Sejm seats for the Polish United Workers Party (Polska Zjednoczona Partia Robotnicza, PZPR) and its allies (the Democratic Party, SD and the United Peasant Party, ZSL). The Solidarity union was therefore permitted to compete in genuinely free and fair elections for the remaining 35 percent of Sejm seats. In this way, Solidarity was able to participate as an opposition party in the decision-making process, while 
the communist government was ensured a numerical majority of at least 299 of the 460 Sejm seats needed to lead a government (Howard \& Brzezinski, 1998, p 135).

Thirdly, the Roundtable Agreement gave the president's office important independent state powers in foreign and security affairs. At that time General Wojciech Jaruzelski, a ruling party first secretary and pro-communist president, occupied the office. According to the agreement, the Sejm and the Senate together as a national assembly had to elect the president's office for a renewable five-year term. This replaced the Council of State with a new and a quite powerful presidency. This agreement was supported by the governing party PZPR, as a safeguard of the interests of the nomenklatura. After the Roundtable agreement, the PZPR knew they could not rely on the Parliament, and therefore they tried to retain control over the executive branch. However, the amendment to the Constitution did not clarify the president's constitutional and power of appointment rights deliberately, on the assumption that a communist president would utilize whatever prerogative he saw necessary. This alone illustrates that both sides, the opposition and the ruling party, attempted to compromise with each other by turning a blind eye to ambiguously defined positions in the Constitution.

Lastly, the Roundtable Agreement provided independence for the judiciary branch, describing judicial independence as significant for a state to maintain the rule of law and the protection of citizens' rights and interests. Following this, a new national judicial council (in Polish, Krajowa Rada Sadownictwa, KRS) composed of representatives from all three branches of government would be given special power to select and propose judicial candidates to the president. Additionally, the Constitutional amendments ensured that the Supreme Court judges were elected for a life tenure (Howard \& Brzezinski, 1998, pp 136-137).

To sum up the Roundtable Agreement achievements, the Council of State was replaced by the presidency as a part of the executive branch and through negotiations, the pro- 
communist PZPR secured effective control over the executive branch, the presidency, and the army. Solidarity, on the other hand, obtained veto rights over initiatives of the communists by their presence in the Parliament. Although the Roundtable Agreement was considered successful for the opposition's bargaining for a political presence in Polish politics, neither side anticipated how quickly the opposition would gain control of both the presidency and parliament.

\section{Steps towards Democratization}

On 4 June 1989, Poland held its first free and fair national elections based on the April Roundtable Agreement. Due to impoverishment, failure of communist-led policies, and the high level of corruption by the then ruling party, Polish United Workers' Party (PZPR), Solidarity candidates won sweeping victories, both in the Senate, 99 out of 100 seats, and seats open for a free election in the Sejm (Sanford, 2002, pp. 54-55). The Solidarity party members restored their complete presence in the Senate and partial presence in the Sejm so quickly that once loyal and obedient allies of the ruling PZPR party, the ZSL and the SD switched their allegiance to the Solidarity party, leading to the balance of powers between both the ruling party and the opposition in the Sejm. The new Sejm was made up of 173 PZPR, 161 Solidarity, 76 ZSL, 27 SD, 10 PAX, and 5 CSU deputies, as stipulated in the Roundtable agreement (Sanford, 2002, p. 55).

One month later, on 4 July 1989, General Jaruzelski was elected to the presidency by the National Assembly. Soon after this, General Jaruzelski appointed another communist general, Czeslaw Kiszczak, as his prime minister. However, without the support of the ZSL and the SD, Kiszczak was unable to form a government. Instead, the Solidarity-led parliamentary coalition government was formed together with the ZSL and the SD. A newly 
formed coalition government elected Tadeusz Mazowiecki, a Catholic journalist and long-time advisor to Lech Walesa, then a prominent figure in the Roundtable negotiations, as the leader of the new government. During the formation of a coalition government, Mazowiecki in a compromise allowed the communists to join a new government so the communists would be able to retain some of their power. This, in turn, indicated that the communist party had lost its grip on power, and the partial presence of the communist party in the newly formed Polish government prevented a harsh resistance and conflicts in Polish political life, which could otherwise have resulted from an abrupt transition of power. The 1989-1991 period was characterized by rapid institutional transformations, and these changes would likely not have occurred so easily and quickly without the Roundtable Agreement among the opposition, Solidarity, and the communist ruling party, PZPR (Howard \& Brzezinski, 1998, p 137).

Following the formation of the new National Council of the Judiciary, constraints on the electoral law and candidate selection were abolished, and the Judiciary legalized a variety of civil and political rights of expression and association. Although the April amendment initiated a systematic change of the regime, there were still traces of the old Polish People's Republic (Polska Rzeczpospolita Ludowa, PRL) government. Therefore, another Constitutional amendment was needed to confirm the fall of the old system (Sanford, 2002, p. 57).

On 29 December 1989, the Sejm introduced the December amendments to legalize the new institutions of democracy. According to the amendment, Article 1 proclaimed that "the Republic of Poland is a democratic state ruled by law, implementing principles of social justice" (Howard \& Brzezinski, 1998, p 138). This law particularly portrays the Rechtsstaat ${ }^{17}$

\footnotetext{
${ }^{17}$ The Rechtsstaat principle hails from nineteenth-century German legal culture and holds that the state has an obligation to be guided by certain principles of justice, fairness, and equity in its relations with individuals (Brzeziniski, 1997, p. 88). European constitutional courts have developed a rich jurisprudence through their enforcement and interpretation of the Rechtsstaat clause. Therefore, Poland's new article 1 was modeled on
} 
principle, Western European constitutionalism. The new Article 2, on the other hand, modeled an old the Polish Constitution of 1921, stating, "supreme authority in the Republic of Poland is vested in the Nation" (Howard \& Brzezinski, 1998, p 138). This article illustrated that the power was now vested in the hands of the Polish nation rather than communist officials. Additionally, new changes to the Constitution included the abolition of its preamble and its first two chapters on the socio-economic and political system of the Polish People's Republic. This, in turn, paved the way towards the gradual privatization of property and the transition from a government-controlled market system to a free-market system. The old Polish People's Republic (PRL) was renamed the Republic of Poland, the original name of the Polish state and the Polish national emblem, the White Eagle, was restored in the national coat of arms (Howard \& Brzezinski, 1998. Sanford, 2002).

After the April and December amendments, Poland's Constitution elucidated checks and balances of power in the country, with legislative and executive powers balanced against each other, and the genuine independence of the judicial branch. With the above-mentioned changes, both Poland's constitutional framework and its institutional system resembled a democratic system. The April and December amendments were considered a blueprint of the democratization process in Poland, and there were further amendments during the 1990s. For example, the 1990s amendments prepared Poland for the first People's Council elections regulated Jaruzelski's withdrawal and registered the first free and fair election for the presidency (Sanford, 2002, p. 57). Once the constitutional and institutional framework had been altered, the personal aspect of the administration was to be replaced by persons loyal to the new democratic order. In this regard, many civil servants, diplomatic officials, judges, rectors, and inspectors working at higher education and schools were replaced, given

the Rechtsstaat clause so it became possible for the Polish judicial branch to look to German and other Western European interpretations of the clause. 
retirement, or threatened with imprisonment for their corruption. On the economic aspect, personnel in the financial sectors quickly implemented the legal and financial framework for the establishment of a single market system in Poland. Following this, the privatization of many shops, restaurants, and services was carried out easily without any hindrance from the government. Additionally, the State Treasury confiscated the old government enterprises of pro-communist officials.

By late 1990, Poland was on a path to democracy and free-market system. Free and fair presidential election by universal suffrage allowed Solidarity, the democratic-opposition camp, to defeat the old pro-communist regime and push for democratization of the regime in the country. However, Sanford, a Polish scholar, states that the triumph of the Solidarity party and ongoing changes of the Constitutional and institutional framework was not felt psychologically. The old personnel of the communist era were not fired from their jobs, rather some of the pro-communist personal secured high-ranking jobs. Throughout the 1990s, unemployment rates increased and living standards fell, despite the economic rearrangements. Democracy was not bringing prosperity to the people, and thus the high hopes and enthusiasm of the summer 1989 Solidarity movement slowly faded. Therefore, many began to blame the leadership of Solidarity, namely, Lech Walesa, for compromising with the communist system and not ending the communist system quickly enough. In other words, the masses wanted accelerated democratization and the end of the transition process. The replacement of a state socialist political and state-controlled economy with democratic capitalism proved to be a tedious and confusing mixture of conflicting principles and mechanisms (Sanford, 2002, pp. 66-67). The social costs of the economic transition and democratization for the nation had been so traumatic that many people, especially the elderly, started feeling hopeless and apathetic. Criminality, drunkenness, and suicide rates also increased. Because of this, trust in public institutions declined from 50 percent to 42 percent in June 1991. The so-called 'honeymoon 
months of the transformation' (Sanford, 2002, p. 67) did not last long. However, in the new political order, the opposition, or people unhappy with the de-communization process, chose the path of protest to show their anger instead of violent social or national conflicts. During the transition, Poland did not experience any violent conflicts, rather, the exchange of powers took place smoothly.

The democratization took place gradually with incremental changes by the fully free and genuine parliamentary elections of 1991, 1993, 1997, and 2001. During 1991-1993, the new regime witnessed two governments of Olszewski and Suchocka and saw Pawlak's failed aspirations. In 1993, electoral thresholds were introduced, pushing parties toward forming alliances. Soon after, the character of the 1997 election created the AWS-UW majority coalition government supporting a Buzek government and produced plurality in the electoral system (Sanford, 2002, p. 61).

According to the polls, people satisfied with a newly formed regime comprised 38-37 percent in 1990, whereas a year later the numbers fell to 27 percent in 1991 and rose to 32 percent in 1992 due to economic challenges. However, gradual economic growth increased the number of people approving democracy to 50-57 percent in 1995-1997 (Sanford, 2002, p. 63). By 1995, a newly formed government was regarded as free and democratic by 38 percent.

\section{Constitutional Changes}

To democratize the Polish political system, a whole set of new legal provisions was needed to replace the old 1952 communist Constitution of Stalin. The April and December amendments introduced in 1989 and 1990 were only piecemeal changes and needed to be extended. New amendments in December also included a reconstruction of the economic system, which would transition a centrally planned economy to market capitalism. Specifically, 
a 'capitalist' style of economic management was created with a single market system and led to the privatization of businesses. A new amended article 6 now stated that "The Polish Republic guarantees freedom of economic activities regardless of the form of ownership," and article 7 stated "The Polish Republic protects ownership and the right to inheritance and guarantees full protection of personal ownership" (Castle \& Taras, 2002, p.190).

Another major constitutional amendment addressed the reorganization of local government in the country. On 8 March 1990, based on the new system, the parliament adopted French-style communal assemblies and regional prefects rather than democratic centralism ${ }^{18}$. According to the new system, local governments had to rely on a self-financing government structure rather than central budgetary allocations. This, in turn, allowed local governments to operate more independently than in the past. Most importantly, in 1990, the procedure for the presidential elections was set out. Article 32 set out the regulations of the election as direct; the term of presidential office had to be five years; and most significantly, the powers of the president were separated from those of the parliament. The article explicitly stated that the president is "the supreme representative of the Polish state in internal as well as external affairs" (Castle \& Taras, 2002, p.190).

The new government of Walesa attempted to introduce more sweeping changes in 1992 and produced a much-updated version of an old Constitution, which was called the 'Little Constitution' of October (Castle \& Taras, 2002, p. 189). However, despite many improvements in the amended articles, there were still disagreements over very basic questions such as how to refer to citizens in the article as 'the Polish nation' or as 'all citizens of Poland.' Another disagreement to be settled was the role of religion. More specifically, in the past Catholicism played a special role in the country, including in Polish political life. Therefore, many lawmakers questioned whether Catholicism should be explicitly recognized in the new

\footnotetext{
${ }^{18}$ It means control by higher party-state bodies over local authorities.
} 
Constitution as the religion of the country or whether it should be denied a special Constitutional status. In everyday life, it can be said that the above-mentioned issues were not so crucial and could be resolved; however, religion and national identity were sensitive issues in Polish society.

The Constitutional Tribunal created in 1992 was a significant step towards distinguishing the powers of the president and those of the branches of government (Castle \& Taras, 2002. Sadurski, 2019). Based on the Constitutional Tribunal directorate in the 'Small Constitution' adopted in 1992, Poland had "a presidential-parliamentary system of governance" (Castle \& Taras, 2002, p. 191). The Small Constitution set out the explicit distribution of powers among branches of government. The authority of Sejm as supreme in the country was dropped, though its significance for legislative approval remained. Despite many improvements in the Small Constitution, some questions remained unresolved, and therefore, a mutual agreement on a completely new Constitution was highly desirable for the democratization process.

After long negotiations among different actors in Polish political life, the Constitution was finally adopted in May 1997, incorporating references to both the Polish nation and its citizens, and both Catholicism and other faiths. In general, the Constitutional Tribunal that was formed in 1992 contributed positively to the Polish democratic governance. Following are some examples of CT achievements; the new Constitution:

- Clarified the relationship between the legislative and executive branches, elucidating the notion of the autonomy of parliament and the controlling functions of the parliament; 
- Limited the role of the Prime Minister in determining the composition of the Council of the Civil Service against a general discussion of the principle of separation of powers;

- Determined, in some detail, the circumstances in which courts may refuse to register a political party;

- Identified the limits of the right to set up associations;

- Determined details of the process of legislative initiative;

- Determined details of the role of social consultation in the lawmaking process;

- Clarified the scope of amendments the Senate could introduce to a statute already adopted by the lower chamber of Parliament (Sejm);

- Established that the president has no prerogative to appoint or revoke the president of the National Broadcasting Board (Sadurski, 2019, p. 60).

\section{NATO and EU Accessions as an External Anchor for Democratization}

The geographical location of Poland in the central lowlands of Europe, with no natural borders between the east and the west, has made the country more susceptible to threats from neighboring countries, especially from the Russian Empire during the first and second World Wars. The indifference of the West to Poland continued well into the twentieth century during the Second World War. Thus, it is not surprising that Poles feel abandoned by the West. However, the Cold War between the United States and the Soviet Union changed this, and in 1995, the United States Defense Secretary William Perry called Poland "the key to European security" (Castle \& Taras, 2002, p. 226). A diplomatic competition between the Cold War superpowers — the United States and Russia—pressed forward the idea of NATO expansion to include Central European countries. However, before granting full membership in NATO to 
former communist states-Poland, Czechoslovakia, and Hungary-the United States mandated a systematic approach. From the West's perspective, Poland had to join the European Union first to strengthen its institutional, political, and economic capacity and then come under the Western security umbrella. For the Polish government, on the other hand, close integration with the West politically, economically, and militarily had to be carried out simultaneously.

To mitigate the presence of Russia in Europe, the Republican majority in the U.S. House of Representatives passed a resolution supporting NATO expansion. This announcement triggered Russia to threaten to scrap bilateral agreements if Poland, Hungary, and Slovakia were admitted into the Western military alliance (Castle \& Taras, 2002, p. 227). Despite the threats from the Russian government, Poland, as well as the other two Central European states, would be admitted into NATO in the spring of 1998. From the perspective of the Polish government, the inclusion of Poland into NATO not only carried security guarantees, but membership in NATO was seen as a promotion of democratic values. Following this, NATO membership significantly jeopardized Poland's relations with Russia. After several threats by the Yeltsin government, Polish leaders altered their foreign policy, pivoting towards Western allies and showing an interest in joining the EU. As the EU is a strong promoter of democratic values, inclusion in the EU was another step towards democratization in Poland.

Since the formation of the European Union (EU), many nations in Europe have feared losing their national identity because of pushes for greater political and cultural integration. Poland is not an exception to this apprehension. However, for Poland, joining the EU meant drifting away from the former Soviet bloc, and therefore, even before the 2000s, optimists predicted the country would become a member of the EU. However, few anticipated that joining the EU would be such a long, complicated process. During the 1990s, Eastern European countries were experiencing rapid political changes and hence collapse of the Soviet Union 
allowed 12 countries to be listed as potential members of the EU. The EU, however, hesitated about whether to expand so quickly.

The first step towards membership in the EU was joining the Council of Europe in November 1991. After two years, Poland received associate membership status in the EU, and in April 1994, Poland formally applied for full membership. After four years, the EU formally initiated accession negotiations with Poland and three other formerly Communist countries, Hungary, Czech Republic, and Slovakia.

In its process towards membership to the EU, Poland had to adopt many constitutional, political, and economic changes to its system, as well as introduce new polices to meet European standards. The differences in the income, judiciary system, immigration, agriculture policy, and environmental standards were the crucial problems to be solved before accession. For example, according to European standards, Poland had the lowest number of interstate highways compared to other European countries (Castle \& Taras, 2002, pp 223-4). Unemployed levels were high, with many Poles showing an interest in migrating to wealthier European countries after accession. Many Western countries, in turn, feared that accession of four ex-communist countries to the EU at the same time would bring a huge migration from Central and Eastern Europe. Because such scenario took place in 1992, when Portugal joined the EU, a great number of people moved to the richer EU states in search of higher-paid jobs.

Additionally, since the EU signed the Schengen agreement in 1985, which established an open border regime among member countries, allowing people to cross borders without passports and border controls, it had to incorporate Poland and the other four countries into its Schengen zone. Joining the Schengen zone not only meant free movement of people and goods, but it also carried responsibilities of providing public security and high standards for the member states. Therefore, it was one of the most sensitive issues in the accession talks for both 
sides. Thus, migration was another crucial problem to be discussed before accession (Castle \& Taras, 2002, p 225). Also, experts of the Center of European Political Studies predicted that Poland might be ready for the Schengen membership only in ten years after joining the EU. The inclusion of Poland to the Schengen zone would push all the members to cooperate with their police forces and justice systems. This, in turn, required shared databases and computer systems, which Poland was not able to provide at that moment, due to its scarce resources and unavailability of data. The exclusion from the Schengen, on the other hand, would create challenges for Poland's foreign policy. That would also mean that all Schengen-zone countries would have to enforce border controls more strictly, inducing a feeling among the Poles that they were a second-class member. Exclusion of Poland from the Schengen zone would not bring any benefits for Poland at the grassroots level. Therefore, by 2002, the Polish government was facing the dilemma of preventing public anger at the EU and maintaining elite support in favor of membership at the same time. Despite all the above-mentioned challenges, Poland became a full member of the EU on 1 May 2004 with the treaty of accession signed in April 2003 in Athens.

\section{Conclusions}

One of the defining characteristics of democracy is that the rules of the game are determined by all major political actors and recorded in a constitution. All playing parties have to follow the rule of law, and these rules are written into a country's constitution. The laws that determine rules can be conventions, traditions recognized over time and approved by the assembly in referendums. A country without a solid and working constitution cannot construct democratic institutions. Constitutions identify powers of the different governmental institutions such as president, prime minister, cabinet, parliament, and judiciary and set out the 
responsibilities of these institutions. In Poland, the first step towards democratization was to rewrite the old Constitution, which enabled the country to form democratic institutions and open space for political pluralism. One of the major achievements of the Roundtable Agreement was, therefore, changes introduced into the Constitution. Of course, building democratic institutions was not an easy task, because struggles to topple the authoritarian system in the country were much harder and tedious than many politicians had anticipated. Some of the changes, such as new political and economic structures, occurred swiftly, whereas, in other spheres, change was slow. For example, writing a new Constitution appeared to be both frustrating and exhausting. There were also disagreements over questions such as how a new Polish government should arrange the separation of powers and institutional capacity, and whether the Third Republic should have a presidency or a parliamentary system.

During the initial ten years of the democratic transition, Poland achieved considerable progress in its democratization. Following is the list of achievements Poland was able to accomplish:

$\checkmark$ Removed all the official symbols and conditions of the previous system. Renamed the country from the Polish People's Republic to simply the Polish Republic.

$\checkmark$ Created the political institutions of democracy, including the presidency and a system of local governments that operated independently. Altered the parliament from unicameral to bicameral, creating the Senate.

$\checkmark$ Replaced the old Polish Constitution of 1952, which was drafted during the Stalin era, by the new Constitution that set out all the rules of the political game, separation of powers, and responsibilities clearly. The updated and finalized Constitution of 1997 enhanced the rule of law, and rights of citizens, and gave real autonomy to the Constitutional Tribunal, an appellate body. 
$\checkmark$ Enacted electoral laws that would govern multiparty competition and ensure fairness of the electoral process.

$\checkmark$ Created a new institutional framework for economic activity and regulations that would enable the economic sector to transition from a government-controlled market system to a single market system. Particularly, legislation to expand private ownership rights was introduced to limit state ownership rights.

$\checkmark$ Safeguarded principles incorporating civil rights and ensuring appropriate institutional protection for them. For example, an office of the Commissioner for Civil Rights, created in 1987, was restored and given autonomy.

$\checkmark$ Strengthened the independence of the judicial branch of government (Castle \& Taras, 2002, pp185-187).

Establishing an institutional and political framework that would enable the country to democratize was the most challenging goal for the new regime. Despite all the challenges encountered by the new government, a new Constitution that would set out political rules of the game was created and ensured democratic values would be respected in the country. Following the creation of the Constitution in 1997, which paved the way towards democratization, Poland aspired to join NATO and the EU. First, in 1998, Poland became a member of NATO, despite Russian threats. For Poland, joining NATO did not necessarily mean obtaining a security umbrella, but it did represent a closer relationship with the Western states that promoted democratic values in the region. NATO, on the other hand, was considered not solely a military alliance but was also a promoter of democratic values.

Following membership in NATO, Poland expressed an interest in joining the EU. One of the most important reasons many Polish political leaders supported accession to the EU was the belief that joining EU would enable the country to be more democratic and strengthen democratic values in Polish society. Many expected that integration into the European Union 
would provide a stimulus for democratization and protect against authoritarian and populist excesses. Political leaders at that time hoped that membership in the EU would set out constraints on the political structure of the state that would protect democratic values. For example, a Copenhagen criterion for the accession is believed to render democracy more resilient against threats, challenges, and populist attacks. A Copenhagen criterion, indeed, helped Poland consolidate democratic values and absorb norms conducive to the rule of law. Once all the criteria were met and Poland was identified as eligible for the accession, Poland integrated into the European Union in 2004. Following membership in the EU, Poland's scores in Freedom House had improved and Poland was identified as a consolidated democracy in 2005 (Freedom House, 2020). The following table will provide a better picture of the democratization in Poland from 2005 until 2015.

\section{Table 2}

Nations in Transit: Poland 2005-2015

\begin{tabular}{|l|r|l|l|l|l|l|l|l|l|l|}
\hline Year & NDG & EP & CS & IM & LDG & JFI & CP & DS & DP & RC \\
\hline 2005 & 5.50 & 6.25 & 6.75 & 6.50 & 6.00 & 6.00 & 5.00 & 6.00 & 83.33 & CD \\
\hline 2006 & 5.25 & 6.25 & 6.75 & 6.25 & 6.00 & 5.75 & 4.75 & 5.86 & 80.95 & CD \\
\hline 2007 & 4.75 & 6.00 & 6.50 & 5.75 & 5.75 & 5.75 & 5.00 & 5.64 & 77.38 & CD \\
\hline 2008 & 4.50 & 6.00 & 6.75 & 5.75 & 5.75 & 5.50 & 5.00 & 5.61 & 76.79 & CD \\
\hline 2009 & 4.75 & 6.00 & 6.50 & 6.00 & 6.00 & 5.75 & 5.25 & 5.75 & 79.17 & CD \\
\hline 2010 & 4.75 & 6.25 & 6.50 & 5.75 & 6.25 & 5.50 & 4.75 & 5.68 & 77.98 & CD \\
\hline 2011 & 5.25 & 6.50 & 6.50 & 5.75 & 6.25 & 5.50 & 4.75 & 5.79 & 79.76 & CD \\
\hline 2012 & 5.50 & 6.75 & 6.50 & 5.75 & 6.25 & 5.50 & 4.75 & 5.86 & 80.95 & CD \\
\hline 2013 & 5.50 & 6.75 & 6.50 & 5.50 & 6.25 & 5.50 & 4.75 & 5.82 & 80.36 & CD \\
\hline 2014 & 5.50 & 6.75 & 6.50 & 5.50 & 6.50 & 5.50 & 4.50 & 5.82 & 80.36 & CD \\
\hline 2015 & 5.50 & 6.50 & 6.50 & 5.50 & 6.50 & 5.50 & 4.50 & 5.79 & 79.76 & CD \\
\hline
\end{tabular}

NDG - National Democratic Governance EP - Electoral Process

CS - Civil Society

IM - Independent Media

LDG - Local Democratic Governance
JFI - Judicial Framework and

Independence

$\mathrm{CP}$ - Corruption

DS - Democracy Score

DP - Democracy Percentage

RC - Regime Classificati 
Notes on Methodology: Nations in Transit scores have been inverted and an additional Democracy Percentage has been introduced to align with other Freedom House reports. Each country is ranked on a scale of 1-7, with 7 representing the highest and 1 the lowest level or democracy.

Key:

$\begin{array}{llll} & \begin{array}{l}\text { Democracy } \\ \text { Score }\end{array} & \begin{array}{l}\text { Democracy } \\ \text { Percentage }\end{array} & \text { Old Scale } \\ & 5.01-7.00 & 100-66.68 & 1.00-2.99 \\ \mathrm{CD}=\text { Consolidated Democracy } & 4.01-5.00 & 66.67-50.01 & 3.00-3.99 \\ \mathrm{SCD}=\text { Semiconsolidated Democracy } & 3.01-4.00 & 50.00-33.34 & 4.00-4.99 \\ \mathrm{~T} / \mathrm{H}=\text { Transitional / Hybrid Regime } & & & \\ \mathrm{SCA}=\text { Semiconsolidated Authoritarian } & & & 5.00-5.99 \\ \text { Regime } & 2.01-3.00 & 33.33-16.68 & \\ \begin{array}{l}\mathrm{CA}=\text { Consolidated Authoritarian } \\ \text { Regime }\end{array} & & & 6.00-7.00\end{array}$

Please refer to full methodology for more details: https://freedomhouse.org/reports/nationstransit/nations-transit-methodology 


\section{CHAPTER IV: WHAT HAS GONE WRONG}

\section{WITH DEMOCRACY IN POLAND?}

Poland made impressive gains during its democratization phrase between 1989 and 2015. Its economy became significantly more open; formal institutions underwent dramatic changes in checks and balances. The judiciary became independent, and foreign and trade policies changed completely from a closed system to a more open and decentralized one. Yet the task of sustaining the impressive performance of democratic institutions has become increasingly difficult after the victory of the Law and Justice Party (PiS) party during the 2015 elections. Since PiS came to power, several changes and amendments ${ }^{19}$ to the Constitutional Tribunal Act were introduced that threatened the independence of the Tribunal, and put constraints on the independence of the media, civil service, police, and prosecution laws. These moves were condemned by international actors such as the European Union and advocates of democracy, calling the changes undemocratic.

A large body of literature offers various explanations about what has gone wrong with the democratization process in countries like Central Asia, much of sub-Saharan Africa, the Persian Gulf states, or Latin American states. "Democratization is less likely in countries with weak institutions, in single-party regimes, in rentier states, in poor countries, in countries with low linkage to the West, and regimes born out of violent revolutions" (Sadurski, 2019, p. 162). However, the Polish case presents a puzzle, as Poland's antidemocratic transformation does not fit any of these explanations. Poland has close ties with the West, is economically stable,

\footnotetext{
19 "Article 5.5 of the Constitutional Tribunal Act stipulates that a person elected to the office of a judge shall take the oath from the President of the Republic of Poland. The refusal to take the oath shall be equivalent to a resignation from the office of a judge of the Tribunal (Art 5.6). On 19 November 2015, the newly composed Parliament amended the Law in respect of the Constitutional Tribunal, which inter alia enabled the dismissal of the previously appointed judges. On November 25, the Parliament annulled the election of all five judges, and a week later, on December 2, resolved to appoint five new judges, from whom the President took the oath immediately", (Sava Jankovich 2018).
} 
has a multi-party regime with a healthy state, and does not have oil. So what has gone wrong with the Poland's democratization process, and how can we explain democratic backsliding? In this chapter, I reflect on the PiS party's changes and offer an alternative explanation to Poland's democratic backsliding.

\section{Polish Political Landscape Before 2015}

To understand what has happened in Poland since 2015, a brief recapitulation of the events before this turning point is needed. The year 2005 was a great year for the Kaczynski brothers, as Lech Kaczynski won the presidential election, and Jaroslaw Kaczynski became the prime minister of the country. However, Kaczynski's government did not last long (2005-2007) because of the government's scandals and constant quarrels within the coalition parties (nationalists and populists). By 2007, a coalition government that proved to be a disaster led to a referendum and early elections. Donald Tusk, a liberal-conservative and pro-European party leader of the Civic Platform (Platforma Obywatelska, PO), won the election and became the prime minister, while Lech Kaczynski remained as the president. Donald Tusk, who promised stability and economic growth after years of political and economic upheaval, was able to restore order in the country. Economic modernization and political stability were the pillars of Donald Tusk's popularity in his first term (2007-2011) as prime minister. However, in his second term (2011-2015), government official's corruption scandals, and abusive behavior affected his popularity and trust in his government. His slogan, 'good economic performance and modernization of the society,' which he campaigned on no longer brought optimism among

citizens, but rather caused people left out from the economic transformation to express 
frustration and resentfulness towards Warsaw elites (Buras, pp. 136-137). While corruption scandals led to a decline in support for the PO party, the weaknesses of the new Polish welfare, mismanagement of the healthcare system, and absence of social protection against abusive officials became the causes of public hostility towards political elites among the citizens living in less developed areas. The anger of the masses was directed not only towards the government, but people became more and more resentful with the new order, new institutions, and elites who promoted liberal values (Jacek Kucharczyk, 2018).

This paved the way for Kaczynski's return to power in 2015. A key event on his way back to power happened in 2010 , when his brother and then president of the country, Lech Kaczynski, died in an airplane crash near Smolensk with other high-level politicians. Jaroslaw Kaczynski and his party launched a conspiracy theory accusing Tusk's government of aligning with Putin and assassinating Lech Kaczynski and the other politicians. Beyond Kaczynski's coming to power after five years, it was the 'instrumentalization' (Buras, p. 137) of the Smolensk crash that became one of the key mechanisms mobilizing right-wing voters against the government. This led to the polarization of political parties. Jaroslaw Kaczynski was able to skillfully fuel resentment among right-wing voters and devoted Christians, the elderly, uneducated, and poor to convince voters of his narrative that Poland was in ruins, and supporters of communism were still operating in the regime.

\section{PiS Party during 2015 Elections}

The outcome of 2015 election can be interpreted as a manifestation of the conflict between 'liberal Poland' and the 'Poland of social solidarity' (Jasiewicz, 2008, p. 8). The PiS party began promoting populist themes and slogans in its electoral campaign even before the 2015 election. In 2015 elections, the two major parties released manifestos and slogans with 
quite different visions of political, social, and economic structure. The PO party promoted 'Green Island' ${ }^{20}$ referring to good economic growth, procedural economy, liberal values, and market freedom (Buras, 137). The PiS party, on the other hand, emphasized national community based on shared values and traditions, the importance of Catholic Christianity, economic unity, and equal redistribution of economic benefits, often with an anti-establishment bent $^{21}$. Specifically, Kaczynski has always campaigned against political elites of the Third Republic, ${ }^{22}$ calling the transformation of 1989 a corrupt system of informal connections running the new regime and an economy composed of ex-communists united by greed, bribery, and nepotism. There is no doubt that the members of the communist party had the means to benefit in the process of privatization, economic liberalization, and democratization, but it is still hard to believe that a powerful network of former communists governs Poland.

Catchy manifestos and exaggerated promises are often displayed during any electoral campaign. In the manifestos of the PiS, however, some slogans and expressions imitate populism. For example, the expansion of executive branch power because of the allegedly corrupt and inefficient legislature and judiciary, representation and protection of 'real people' from the abuser of political elites, fighting against the establishment, bringing back national and religious Catholic norms, providing national and personal security from outsiders (Muslim refugees) are the promise, the PiS party made in the speeches addressed to the nation in 2015. Jaroslaw Kaczynski stated in a speech:

\footnotetext{
20 "Civil Platform. Postulates and actions of the largest opposition party" https://ideologia.pl/program-partiiplatforma-obywatelska/ (Accessed in October 13, 2020).

${ }^{21}$ Following is the collection of the most important promises of Law and Justice (PiS), which were made in the presidential and parliamentary campaign 2015.

https://www.polityka.pl/tygodnikpolityka/kraj/1639099,1,przypominamy-obietnice-pis-wydrukuj-izachowaj.read (Accessed in October 13, 2020).

${ }^{22}$ The numerical ordering is commonly used to refer to the consecutive reincarnations of a sovereign Poland. The First Republic existed in the late eighteenth century, Second Republic from 1918-1939, until it became a part of Soviet Union. And, the Third Republic was born in 1989 after Polish People's Republic was renamed as the Polish State.
} 
"We must repair the Polish legislative system, which is deeply ill today. It produces a huge amount of recipes that no one understands anymore and no one is able to use them anymore. And most of the laws are simply fiction. Polish courts need to be changed! Because today they are not an organ of the judiciary. The prosecutor's office needs to be changed, because it is not responsible to anyone today. We need to sort out the issue of uniformed services and secret services, we need to reform our territorial administration to some extent" 23

The PiS party's success lay in the fact that it managed to mobilize nearly all social groups $^{24}$, including its base voters, culturally traditionalist (Catholic church-goers), economically hard-pressed voters who dwell in the countryside, less educated, older and poorer voters (Tworzecki, 2019, p. 104). The socio-economic and socio-cultural divide in society allowed the party to attract new supporters. In the electoral campaign, Jaroslaw Kaczynski, the PiS party's chairman, argued that the Polish state was not working as promised by the political elites. Only his party would be able to fix it. This approach is best reflected in the slogan of Law and Justice (PiS): 'Listening to Poles, changing Poland'25 and PO's slogan: “"Komorowski - prezydent naszej wolności (in English Komorowski - the president of our freedom)",26

\footnotetext{
23 " Two ways for Poland according to Jarosław Kaczyński" https://tvn24.pl/polska/cale-przemowieniejaroslawa-kaczynskiego-w-warszawskim-kinie-wisla-ra584002-3314394 (Accessed in October 12, 2020). ${ }^{24}$ Surveys conducted in the 2010 presidential and 2011 parliamentary elections show that a vote for PiS is mostly based on religion, dissatisfaction with democracy. Also people living in northwest of Poland more often voting for PO while in the southeast there is a preference for PiS. For more see Claudia-Yvette Matthes (2016) "The State of Democracy in Poland after 2007. Analyzing the linkage between economic development and political participation"

25 "PiS's new election slogan. Kaczyński's party will convince voters with it?" https://wiadomosci.dziennik.pl/wybory-samorzadowe/artykuly/471850,jaroslaw-kaczynski-i-adam-hofmanpokazali-haslo-wyborcze-pis.html (Accessed in October 12, 2020).

26 "The president presented a new election slogan" https://tvn24.pl/polska/prezydent-zaprezentowal-nowehaslo-wyborcze-ra542347 (Accessed in October 13, 2020).
} 
The slogan of the PiS party was presented to a nation during a press conference by Jaroslaw Kaczynski, stating that Poles only want improvement of reality rather than miracles. During the conference, Kaczynski argued that the regime's transformation did not benefit all Poles equally and the new system did not function well. He spoke about the need to improve the labor market, care for families, and provide better health care. He stated only his party would help Poles and protect them from abuses of Warsaw elites: "ludzie często są pozostawiani sami sobie, nie mają wsparcia, nie mają żądnej pomocy ze strony rządzących, (in English "people are often left on their own, do not have support, do not have any help from the rulers)"27. Piotr Buras states:

“Kaczynski’s promise was one of community, strong identity, leadership, anchoring in the Polish tradition and restoring the dignity of people disorientated or concerned about the rapidly changing environment and uncertain future" (138).

The PiS party's manifesto presented a nationalistic and Christian Democratic healthy state with a decisive role in economic and social policies. The approach of the party was to make Poland a strong nation with a strong executive branch. Also, the slogans and manifesto of the PiS for 2015 in Poland reflected an anti-establishment message and a demand to protect ordinary people against elite-driven economic policies. First, Kaczynski skillfully highlighted the refugee crisis in Europe, which gradually created a fear of Muslim refugees among Poles. Hence the European Commission's policy on refugee distribution among the European Union member states has triggered anti-migrant and xenophobic attitudes in ethnically and religiously homogeneous Poland (Sadurski, 2018, pp.164-165). In Poland, the population identifies itself

\footnotetext{
27 “Parliamentary Elections 2015" https://wydarzenia.interia.pl/raporty/raport-wybory-parlamentarne2015/aktualnosci/news-beata-szydlo-zaprezentowala-nowe-haslo-wyborcze-pis, nld,1873402 (Accessed in October, 13, 2020).
} 
as more than 90 percent Christian. Therefore accepting any Muslim from a war-torn Syria was presented as a potential security crisis and hence was considered a public threat.

Secondly, anti-establishment sentiments were strengthened by the PO government's corruption scandals at the end of its second term. During the economic transformation, there were parts of Poland that benefited from the change. In contrast, in the other parts of Poland, the management of economic and political policies was inefficient due to corruption and bribery of political elites. Despite economic growth, political stability, and the decline in unemployment rates, the gap between poor and rich in Poland ${ }^{28}$ remained high, with many people feeling frustrated by the Warsaw elites. Such difference created a perfect excuse for Kaczynski's project to make reforms in the system. In addition, Kaczynski argued that the law erects' obstacles and barriers and renders it impossible to carry out necessary reforms. Buras writes:

“In Kaczynski's conviction, liberal democracy, famously fragile and vulnerable, is an outdated political structure in this globalized and complex world. Instead, Kaczynski believes that what is needed is a strong government that acts efficiently on behalf of the democratic majority and, when necessary, can take drastic measures to carry out the majority's will without being permanently hobbled by the liberal system of checks and balances" (139).

Thirdly, the source of the electoral success of PiS was due to the Polish electoral system. Poland's election turnout is considered to be the lowest among European members. In 2015, the turnout comprised 50 percent, and PiS success was hardly sweeping, as it gained only 36 , 2 percent of the vote. More specifically, if we consider all eligible voters, only 20 percent of all eligible voters gave the party its support (Tworzecki, 2019, p. 100. Buras, p. 138). It was

\footnotetext{
${ }^{28}$ People living in northwest of Poland more often voting for PO while in the southeast there is a preference for PiS.
} 
both the mobilization of the core electorate of the PiS party and a low turnout of liberal centrist voters that proved to be a success for Kaczynski. The Polish electoral system favors a party majority, and therefore, if a party gains the highest number of the votes, it can form a singleparty government. The parties that receive a lower percentage of votes can merge parties and run as a coalition. The threshold for parties to enter the parliament is 5 percent while the coalition threshold is 8 percent (Nardelli, 2015). However, in Poland's case, some 15 percent of votes were wasted because of the inability of small parties to come together or pass the 8 percent threshold requirement as the coalitions (Sadurski, 2018, p. 166. Buras, p. 138). This allowed the PiS party to form a single-party government for the first time since the Soviet Union's collapse.

Regarding voting behavior, one can witness the rivalry of the two parties that position themselves as 'liberal Poland' and 'the Poland of social solidarity.' According to the socioeconomic stratification pattern, better educated, younger, affluent, urban dwellers and proEuropean enthusiasts tended to vote for the PO. Less educated, older, religious, more impoverished, and rural dwellers and Euro skeptics tended to vote for PiS (Tworzecki, 2019).

Dissatisfaction with the existing government and order has given rise to the Populist PiS Party and a demand for a change has been accompanied with the democratic backsliding. What has been remarkably different from other populist parties is the PiS party's ability to conceal its populist tendencies.

\section{Changes Introduced to the Institutions of Democracy}

Since the PiS party came to power, many changes to the democratic institutions have been introduced. One of the most significant changes was in the judiciary system, which paved 
the way towards democratic backsliding and has been carried out under the PiS government. For example, the amendments introduced by the PiS to the Constitutional Tribunal Act. For example, PiS refused to recognize three judges appointed by the previous PO government in October (2015) and elected three quasi-judges in their place. The newly elected president Duda instead of swearing in the October judges immediately, he swore in the three PiS nominate quasi judges during the night, just hours before CT determined that the three elections of October judges were constitutional. At the end of 2016, CT adopted two laws that ruled on the three elected judges' constitutionality. Based on the laws and reinterpretation of the K $34 / 15^{29}$, the three judges gained legitimization. The PiS became confident that now the CT would be an obedient device of the executive branch and would not go against government initiatives on the judiciary or legislative.

The PiS government not only replaced the judges of the Constitutional Tribunal, but it was also able to elect the president of the $\mathrm{CT}$ after the resignation of Andrzej Rzeplinski as president on 19 December 2016. The newly elected president of the CT Judge Przylebska, and the new leadership of the CT became active supporters of the government in times of external scrutiny by the opposition. For example, in 2017, during the public controversy, after President Duda's announcement of the new judiciary bills, Judge Julia Przylebska went on television to pronounce her confidence in the government's bills, stating, 'The bills do not threaten the separation of powers, and they meet the regularities of the Constitution' (Sadurski, 2019, p. 82). During the televised speech, Przylebska even criticized the opposition for provoking allegations that the rule of law was endangered in Poland.

\footnotetext{
${ }^{29}$ The Tribunal ruled on the constitutionality of the Introductory Provisions to the Act on the Organization of the Constitutional Tribunal and the Mode of Proceedings before the Constitutional Tribunal and to the Act on the Status of the Judges of the Tribunal as consistent with the Constitution. For more information see https://trybunal.gov.pl/en/news/press-releases/after-the-hearing/art/9907-ustawy-o-trybunalekonstytucyjnym/ (Accessed in January 27, 2021).
} 
Since the electoral victories of 2015, the Constitutional Tribunal's traditional role as an effective tool to counter majoritarianism in scrutinizing laws concerning their constitutionality has been transformed, first into a powerless institution, unable to review new PiS laws, and then into a positive supporter of the government bills. In other words, the CT became a reliable aide of the government and protector of Poland's majoritarian rule. Sadurski writes:

"The Constitutional designers of the Third Republic saw the CT as the centerpiece for protecting of the rule of law, and constitutional checks upon majoritarian politics. Their judgments eventually created a canon of liberal constitutionalism in Poland. But if one places all one's trust in a small, fifteenperson body to carry the enormous burden of the constitutional control of politics, one makes it easy for populists to dismantle the system by hitting at its centerpiece quickly" (2019, p. 86).

The capture and transformation of the CT were one of the earliest signs of Polish autocratization. Creating and maintaining the judiciary's overall independence was an essential goal during the democratization period in Poland. However, the assault on the CT to effectively transform it from an independent institution to a government tool for its anti-democratic laws has impeded the new democracy in its transition to becoming a consolidated democracy.

In a democracy, parliamentary opposition is an important element of checks and balances. The opposition should be treated fairly and equally. However, under PiS the opposition parties have witnessed systematic marginalization and intimidation other than some friendly opposition with populist-nationalist tendencies. For example, some of the most important legislative changes have been proposed as private members' bills rather than government initiatives. The bills did not go through consultation or expert opinion, but rather an extreme fast-tracking method was used in the parliamentary sessions for new legislative 
bills. In 2016 alone, 40 percent of new legislative bills were submitted as private members' bills. In the Senate and Sejm, PiS party members were able to silence the opposition through the use of mechanisms such as gag rules, ${ }^{30}$ which speeds up the review process without explaining the urgency of the proposals. Sometimes, the opposition MPs were unaware of what they were voting on because of amendments proposed overnight.

The PiS government also set several new parliamentary rules that decreased the discussion time for proposals; the number of questions being raised by party members was dropped to a couple of questions. Because of the limited time for questions and discussion, the right to raise questions was given only to government's supporters. Occasionally, the opposition has found their microphones turned off on purpose during caucuses, and various other procedural tricks have been used to sideline the rival (Sadurski, 2019. pp 133-134).

Soon after the parliamentary and presidential victory, the PiS went after civil service regulations designed to provide the efficiency of state administration. Civil service personnel are not politicians and should not be affected by the political situation or changing governments. However, in the PiS government's case, while new proposals regarding civil service of the PiS party were introduced and approved in the Parliament, the opposition's proposals were rejected. The PiS believed that all civil service workers should be replaced with civil servants who support and understand its policy. The law approved in 2015 altered the legal infrastructure of civil service and initiated a massive purge in public administration. In some institutions, the entire personal were replaced by party loyalists. For example, after the new law was adopted in December 2015 on broadcasting, all 118 senior management positions in public radio and TV were replaced with people who supported the PiS policies (Sadurski, 2019. Pp 136-138). In other spheres such as education, tax, customs, and health department,

\footnotetext{
${ }^{30}$ Gag rules during deliberations, placing new items on the agenda without any notice, and speeding up the deliberation ignoring expert opinions (Sadurki, 2019. P. 133).
} 
top senior positions were filled with party loyalists. The purge of the civil service personal in all areas explains how the PiS government is creating a patron-client system in the country (Tworzecki, 2019, p. 98). In other words, in no democracy should we observe nepotism. This patron-client relationship of the PiS government is one of the signs of its democratic regression.

Immediately after PiS came to power, the entire public media were captured and transformed into a government propaganda tool ${ }^{31}$. All the journalists and TV workers who criticized the PiS policies or questioned their governance were forced to leave their jobs. The legal infrastructure system was changed by statute despite the Constitution, which establishes that the National Council of Radio and TV Broadcasting (Krajowa Rada Radiofonii i Telewizji (KRRiTV)) is responsible for oversight of all TV and radio service. After coming to office, the newly elected President Andzej Duda appointed five members to the National Council of Radio and TV, and three of the members are representatives of PiS. Before 2015, all members of KRRiTV were selected by both the opposition and supporters of the governing party to maintain checks and balances. Today all members of KRRiTV are staffed exclusively with supporters of PiS, and the opposition is not given any chance to elect its member (Sadurski, 2019. p 139). Sadurski writes:

"The government announced that it would propose legislation to 'repolonize' and 'deconcentrate' private media. No doubt, PiS will attempt to reduce the influence of the very rich private media, both electronic and press, in Poland. The Polish media structure makes it relatively easy to 'deconcentrate' them and

\footnotetext{
31 International Press Institute notes that "one of the main news program, Wiadomosci on TVP channel, demonstrates notable bias in favor of the ruling PiS. The bias manifests in both proportionally higher screen time for members of PiS and overwhelmingly positive coverage of the ruling party, the program often casts opposition politicians and their supporters in a negative light. At times it neglects to cover the opposition at all and omits stories that may reflect poorly on PiS" (Gipson, 2019).
} 
in the process, transfer ownership to those who would be friendly to, or dependent on, the PiS government” (2019, p 139).

In fact, in Poland, anti-monopolistic measures were adopted long before the PiS government came to power. International companies cannot own market shares of Polish companies greater than 40 percent. However, the PiS government is thinking of lowering the threshold to 20 or 25 percent, making it harder for external companies to influence the country. Major Internet and press outlets currently belong to German and Swiss companies, while American companies own major TV channels operating in Poland.

\section{How It Happened}

Between 1989 and 2015, Poland attained democratic governance generated by free and fair elections, achieved a rapid improvement of living standards, and secured a membership in both NATO (1999) and the EU (2004). The transition from communism to democracy occurred peacefully in carefully negotiated increments. Based on Carothers's democratization theory, Poland was among the most successful post-transitional democracies in Central Eastern Europe after the Soviet Union's collapse in 1989 (Carothers, 2002, p. 9). According to Schedler, the definition of democratic consolidation should be restricted to only one criterion, which is referred to as "a democratic regime that relevant observers expect to last well into the future and nothing else" (Schedler, 1998, p 103). If we associate Polish democratic consolidation with the continuation of democracy's progress during its democratization phase, we can undoubtedly say that Poland failed in its democratic consolidation.

In the first place, Poland never had sufficient time to consolidate its democratic institutions. The democratization and legitimization of the third Republic have always been questioned by the far right-wing populist politicians, namely, the Kaczynski brothers. In many 
ways, the agreement that held the post- Roundtable political consensus between the governing party PZPR, as a safeguard of the interests of the nomenklatura and the Solidarity grew out of the flawed amendments. More specifically, the Constitution's amendment (1989) did not clarify the President's constitutional power of appointment rights deliberately, assuming that a communist president would utilize whatever prerogative he saw necessary. Both sides, the opposition, and the ruling party attempted to compromise with each other by turning a blind eye to ambiguously defined positions in the Constitution. During the formation of a coalition government, Mazowiecki, as a compromise, allowed the communists to join a new government to prevent violent protests and conflicts between the communists and opposition. According to the PiS narrative, the Roundtable Agreement furnishes the main outlines of Poland's major discursive schism to this day. The Third Republic (post-1989) failed and was tainted by 'uklady' 32 (Harper, 2018, p. 29).

Linz and Stepan argue that a democratic regime is consolidated when there are no political or institutional actors attempting to achieve their objectives by creating nondemocratic policies. In other words, behaviorally, Poland's democracy has not consolidated due to significant interruption of the democratization process (e.g., deep political polarization, low trust in institutions, low political participation, and etc.). Both the PO and PiS have been attempting to articulate the voices and create a schism within civil society. While PO articulated many of the demands of an urban, affluent, liberal, and educated middle class who aspired to be European and liberal, PiS appealed to those of a rural, poor, religious, uneducated, and elderly who were closely tied to the land and the traditions. The Polish political society of the

\footnotetext{
32 "Uklady refers to a nebulous series of networks, of semi-covert groups operating in a half-world comprised of mainly ex-communist politicians and secret service officials and apparatchiks, and which grew up as a direct consequence of the Roundtable deal between the communists and intellectual-liberal wing of Solidarity" (Harper, 2018, p. 29).
} 
post-communist era has been marked with a manifestation of the conflict between 'liberal Poland' and the 'Poland of social solidarity' (Jasiewicz, 2008, p. 8).

Secondly, a democratic regime is consolidated when a substantial majority of civil society believes that democratic institutions and norms are the most appropriate governance style. In consolidated democracies the support for anti-system and undemocratic policies and leaders is small. The victory of the PiS already proves the assumption that despite democratization, Polish civil society has remained indifferent towards democratic regression under PiS governance. Linz and Stepan (1996) argue that civil society, political society, and the rule of law pre-requisites and necessary conditions for a democratic regime's sustenance. By 'civil society,' Linz and Stepan refer to that "arena of the polity where self-organizing groups, movements, and individuals, relatively autonomous from the state, attempt to articulate values and create associations and solidarities advance their interests” (1996, p. 7).

Thirdly, a democratic regime is consolidated when institutional forces such as the Judiciary, the Supreme Court, and non-governmental institutions such as the media become a protector and self-corrector of specific laws that try to alter the functions of a democratic process (Linz and Stepan, 1996, p. 6). Constitutionally speaking, the PiS party was already able to introduce laws to the Constitutional Tribunal, Supreme Court, and broadcasting that altered these institutions into the party's political tools.

A highly polarized and divided society, to a more considerable extent, undermined democratic consolidation. The Polish nation is considered a country that experienced fragile national sovereignty and a precarious national identity due to past' territorial insecurities. The right-wing nationalist ideologies of the PiS, therefore, have been incredibly successful in exploiting fears of cultural change. Kende and Kreko (2020) explain the success of right-wing populism in Poland using a demand-supply framework. Since Poland joined the European 
Union, its culturally homogeneous society has been exposed to highly modernized and liberal ideas such as LGBT rights. These individualistic and progressive ideas were not widespread among Poles. Besides, due to socialism's heritage, most people (e.g., elderly, countryside dwellers, poor, uneducated, and religious) in Poland display core conservative attitudes, resistance to change, and anti-egalitarianism, and therefore strongly attached to fear of change and norm-violating attitudes. In this context, "right-wing populist leaders such as Jaroslaw Kaczynski can successfully emerge as entrepreneurs of identity, exploiting fears of cultural changes" (Kende and Kreko, 2020, p29). For these reasons, anti-democratic political trends can significantly affect civil society where right-wing populist politicians like Kaczynski can fuel prejudice in changing culture.

Thirdly, the articulation of the refugee crisis was the politicization of immigrant threat and the mobilization of the electorate. Xenophobic propaganda by the right-wing populist PiS claiming to represent the ordinary people coincided with an increase in intolerance among Poles towards culturally different immigrants from the Christian population (Kende and Kreko, 2020, pp. 31-32). Harper further describes the above discursive mechanism as one that divides the world into 'good' and 'bad' or 'us' versus 'them' stating:

"This is a discourse that speaks to a particular national tradition, evoking a certain strand of that tradition. It is a mode of political thought and action that also places the Catholic Church at the heart of the concept of the nation and Catholic Poles, by extension, at the center of the national identity and PiS as the party of the Catholic faithful and families" (Harper, 2018, p.30).

The changes introduced since 2015 have tested Linz and Stepan's consolidation theory. Liberals in Poland have succeeded in building democracy institutions, while civil society has remained relatively weak (Rychard, 2018, p. 53). Therefore, the consolidation of democracy 
never took place. The failure of democratic consolidation in Poland and further undemocratic directions of change implemented by the PiS allowed democratic backsliding to take place.

As noted in the introduction, backsliding occurs through a series of incremental changes in the rules and informal procedures that form elections, rights, and accountability. For example, a political actor in an office may initiate a low-level assault on democratic accountability and thereby subvert democracy from within, as is happening in Poland under the leadership of the PiS government. According to Freedom House report on "Nations in Transit" (2020), PiS went further in its violations of Poland's Constitution by passing laws that "permanently hamper the impartial functioning of the courts, rigged the appointment process for judges, created a mechanism to reopen final court rulings, set up a partisan disciplinary regime for the judiciary" (6). The decline in civil liberties, judicial framework and independence, and the political rights in the aftermath of the 2015 elections, illustrate that actions taken by the PiS party contributed to the reversal of democratization progress. If we compare table2 with table3, we can see that Poland's overall democracy score has declined from 83 percent in 2005 to 65 percent in 2020, turning from consolidated democracy to semiconsolidated democracy.

The following table shows a decline in the democracy score in total and by category to give a better picture of democratic regression in Poland since 2016: 
Table 3

Nations in Transit 2016-2020: Category and Democracy Score Summery

\begin{tabular}{|l|r|c|c|r|r|r|r|r|r|l|}
\hline Year & N D G & E P & C S & \multicolumn{1}{c|}{ I M } & L D G & J F I & C & D S & D P & R C \\
\hline 2016 & 5.25 & 6.50 & 6.50 & 5.25 & 6.50 & 5.25 & 4.50 & 5.68 & 77.98 & CD \\
\hline 2017 & 4.75 & 6.50 & 6.25 & 5.00 & 6.25 & 4.75 & 4.50 & 5.43 & 73.81 & CD \\
\hline 2018 & 4.00 & 6.50 & 6.00 & 5.00 & 6.00 & 3.75 & 4.50 & 5.11 & 68.45 & CD \\
\hline 2019 & 4.00 & 6.50 & 5.75 & 5.00 & 6.00 & 3.75 & 4.25 & 5.04 & 67.26 & CD \\
\hline 2020 & 4.00 & 6.50 & 5.50 & 5.00 & 5.75 & 3.50 & 4.25 & 4.93 & 65.48 & SCD \\
\hline
\end{tabular}

\section{CATEGORIES:}

NDG - National Democratic Governance EP - Electoral Process

CS - Civil Society

IM - Independent Media

LDG - Local Democratic Governance
JFI - Judicial Framework and Independence $\mathrm{CO}$ - Corruption

DS - Democratic Score

D\% - Democracy Percentage 


\section{CHAPTER V: CONCLUSION}

This thesis aimed to determine to what extent the rise and victory of the right-wing Populist Party, the PiS, has impacted democratic backsliding in the country. By studying the rise of populism in relation to democratic backsliding in Poland, this thesis aims to offer an alternative framework to the social requisites literature for understanding how elected officials can reverse democratization. To grasp different aspects of developments, I have divided the analytical framework into two periods, starting from 1989 until the PiS party's victory in the 2015 elections and from 2015 onwards to the most recent 2019 developments. The changes since fall 2015 go beyond the usual things associated with a change of government and there seems to be a more strategic aim of remodeling the whole institutional system in Poland. Therefore, in this study of democratic backsliding in Poland, most of my attention is centered on the rise of right-wing populism in the country, which brought success for the PiS party.

Economic distress is a precondition for serious instability, but it is not a sufficient one in Poland's case. A right-wing populist PiS party's rise to power had clear political mainsprings. From Poland's democratic regression, we can learn that declines in democracy scores are not always the result of an institution's instability or mismanaged government. When civil society disbelief for the government officials is accompanied by other structural features of vulnerability, a high risk of democratic backsliding arises, as exemplified in this thesis. The underlying exposure to Poland's backsliding depends on a host of factors, including weak civil society, low public trust in democratic institutions, a history of unrest, high political polarization, and, primarily, discourses of political parties. Rising popular frustration with the political status quo in Poland led to the rise of the right-wing Populist Party, the PiS, and reflected negatively in the overall score of democracy. Democracy Index Report states: 
"In 2019 Poland fell below Hungary for the first time, as Poland's ruling conservativenationalist Law and Justice (PiS) party continued its efforts to turn the country into an ‘illiberal democracy', including by constraining the independence of the judiciary and consolidating media ownership in Polish hands"(2020, p. 31).

The importance of the right-wing party's victory, the PiS, in relation to anti-democratic developments has been repeatedly highlighted throughout this thesis. Indeed, based on the slogans and manifestos of the elections of 2015, PiS appears to be a populist party in its ideology, discursive style, and political strategy.

Since the rise of right-wing populism in Poland, anti-democratic leaders such as Jaroslaw Kaczynski hindered democratization in Poland by launching assaults on the judicial independence and threats against those in the media and civil society who condemn the governing party. Besides, the PiS party was able to manipulate the electoral framework and hollow out parliaments, which stopped fulfilling their role as centers of political debate and executive oversight. Today Poland's democracy suffers from a lack of checks and balances because of reforms introduced by the PiS government. The PiS party plays an outsized role in governance, including by presenting all new legislation and initiatives in the Parliament. To this day, the populist PiS party continues its undemocratic policies while relying on the majoritarian element of democracy, claiming that they act according to the will of people (Freedom House, 2020). For a political order to be democratic it is not sufficient that the leaders are elected democratically, but these democratically elected leaders need to behave within the norms of the democracy as identified by the Constitution. Linz and Stepan states:

"No regime should be called a democracy unless its rulers govern democratically. If freely elected executives (no matter what the magnitude of their majority) infringe the constitution, violate the rights of individuals and minorities, impinge upon the legitimate 
functions of the legislature, and thus fail to rule within the bounds of a state of law, their regimes are not democracies" (1996).

Despite the success of the PiS party and the support, it gained during its first term, nothing can overshadow the party's violations of political and civil liberties. The institutional changes introduced by the PiS party after 2015 have contributed to a decline in democracy scores in Freedom House reports. The following table illustrates how Poland's democracy score has started to decline from 2015 when the PiS came to power up until 2020.

Table 4

Nations in Transit 2020: Democracy Score Summery

\begin{tabular}{|l|l|l|l|l|l|l|l|l|l|l|l|}
\hline COUNTRY & 2010 & 2011 & 2012 & 2013 & 2014 & 2015 & 2016 & 2017 & 2018 & 2019 & 2020 \\
\hline POLAND & 5.68 & 5.79 & 5.86 & 5.82 & 5.82 & 5.79 & 5.68 & 5.43 & 5.11 & 5.04 & 4.93 \\
\hline
\end{tabular}

Countries are rated on a scale of 1 to 7 , with 1 representing the lowest and 7 the highest level of democratic progress. Source: Freedom House 2020.

PiS party's reform method from within through new laws ${ }^{33}$ remained intact and affected consequent parliamentary elections in 2020. Recapture of electoral proceedings and sidelining opposition can be observed in the most recent parliamentary and presidential elections. In both elections, the PiS party and its presidential representative Andrej Duda won due to its effective propaganda in a highly polarized society. The reforms of the PiS in the democratic institutions ignited the European Union's frustration. When the European Commission launched sanctions against the breach of EU values and violating article 7 TEU ${ }^{34}$ Hungary's Prime Minister Victor

\footnotetext{
${ }^{33}$ Amendments to the electoral code endangered the independence of the National Electoral Commission (PKW), which manages elections and overseas party finances, by shifting responsibility for many of its nominations to institutions controlled by the PiS party (Freedom House, 2019).

${ }^{34}$ The European Commission adopted Communication under the title 'A new EU framework to strengthen the Rule of Law.' The aim of the procedure included in the document is to give the Commission more instruments
} 
Orban announced that his government will support the PiS government and will not vote in the Commission. Interestingly, today populist leaders with their authoritarian inclinations support each other in times of crisis. Orban's government in Hungary is another EU member where democratization process has staggered considerably and is rated as transitional or hybrid regime in Freedom house (2020).

The achievements of 1989 and the years of reform that followed have not been eradicated completely. Poland is still rated "Free" in Freedom House (2020) and is still member of both NATO and the EU. However, if assaults on the judiciary, civil liberties, and political society continue, Poland's future democracy future looks grim and in danger of joining autocracies. The following table will provide a clearer picture of democratic backsliding in Poland.

to ensure the observance of values stipulated in Article 2 TEU. The Communication refers to the rule of law, considered to be the backbone of any modern constitutional democracy (Kubin, p. 324). 
Table 5

\section{Poland's Ten-Year Decline}

\section{POLAND'S TEN-YEAR DECLINE}

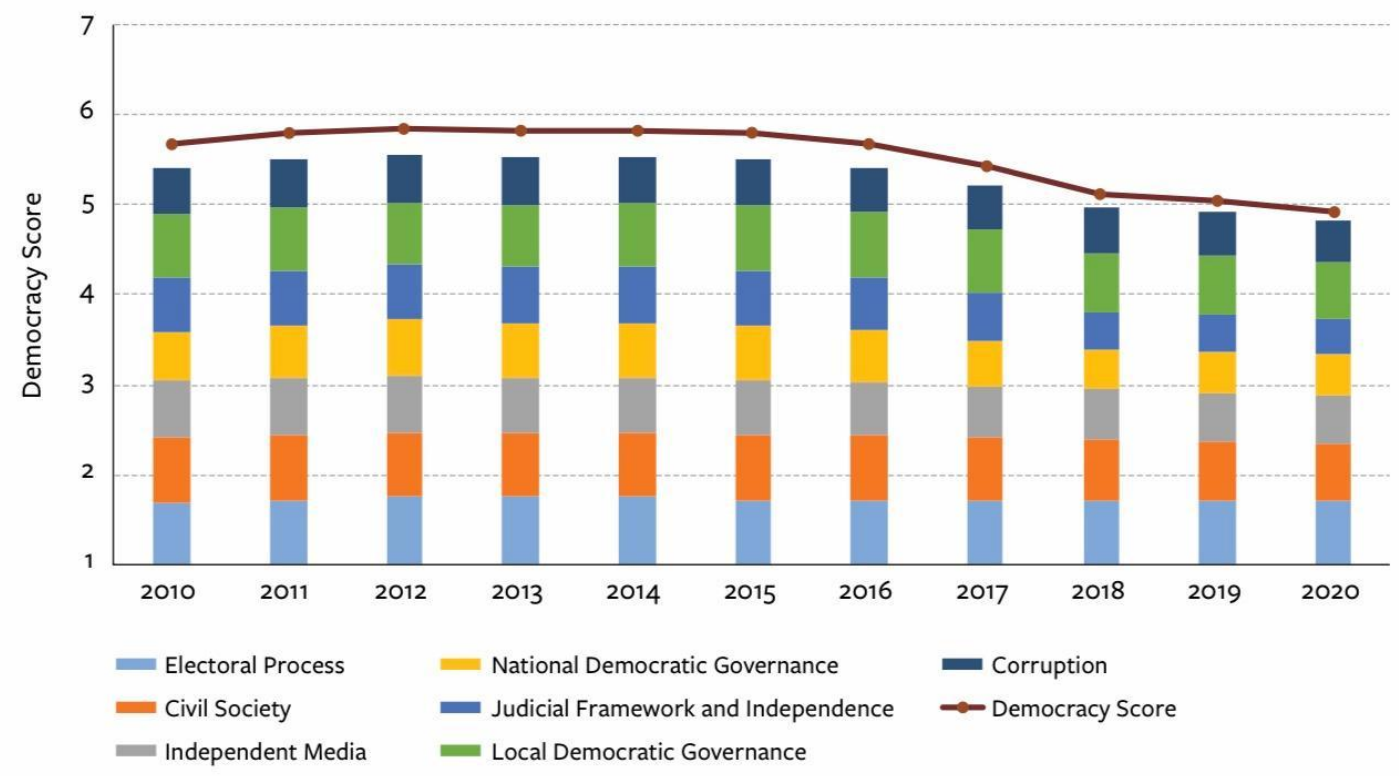

Source: Freedom House 2020 


\section{REFERENCES}

Bermeo, Nancy (2016), “On Democratic Backsliding,” Journal of Democracy, Vol 27(1) (pp 5-19).

Bogaards, M. (2009), "How to classify hybrid regimes? Defective democracy and electoral authoritarianism." Democratization, Vol 16 (2) (pp 399-423).

Bunce, V.J., and S. L. Wolchik (2010) "Defeating Dictators. Electoral Change and Stability in Competitive Authoritarian Regimes," World Politics 62(1) (pp 43-86).

Carothers, Thomas (2002), “The end of the transition paradigm” Journal of Democracy (Vol 13(1), pp 5-21).

Cassani, A. (2014), "Hybrid what? Partial consensus and persistent divergences in the analysis of hybrid regimes,” International Political Science Review, Vol 35(5) (pp 542-558).

Castle, Marjorie and Taras, Ray. (2002) Democracy in Poland. Westview Press.

Cheeseman, Nic, and Brian Klaas (2018), "How to Rig an Election," Yale University Press, Introduction and conclusion (pp 1-31, 207-239).

Collier, David, and Levitsky, Steven (1997), "Democracy with Adjectives: Conceptual Innovation in Comparative Re-search," World Politics, Vol 49-10 (pp 430-451).

Crozier, Michel J., Huntington, Samuel P. and Watanuki, Joji. (1975) "The Crisis of Democracy" Report on the Governmentality of Democracies to the Trilateral Commission.

Diamond, Larry (2002). "Thinking about hybrid regimes." Journal of Democracy 13(2), (pp. 21-35).

Diamond, Larry. (2019) “The Global Crisis of Democracy” The Wall Street Journal. 4 June 1991.

Economist, The. "What's gone wrong with democracy?" 
Economist Intelligence Unit, The (2018) "Democracy Index 2018: Me too? Political participation, protest and democracy"

Ercan, Selen A. and Gagnon, Jean-Paul. (2014) "The Crisis of Democracy Which Crisis? Which Democracy?” Democratic Theory Vol 1(2), (pp 1-10).

Fomina, J., and Kucharczyk, J. (2016). "Populism and Protest in Poland". Journal of Democracy, 27(4), (pp 58-68).

Freedom in the World (2019) "Democracy in Retreat" Freedom House.

Gandhi, J. and Lust-Okar, E. (2009). "Elections under Authoritarianism." Annual Review of Political Science 12(1), (pp 403-422).

Gerschewski, J. (2013). "The three pillars of stability: legitimation, repression, and co-optation in autocratic regimes." Democratization 20(1), (pp 13-38).

Grabowski, Wojciech. (2019) "Determinants of voting results in Poland in the 2015 parliamentary elections. Analysis of spatial differences" Communist and PostCommunist Studies 52, (pp 331-342).

Hartlinski, Maciej (2019) “Twins in power. Jaroslaw Kaczynski and Lech Kaczynski as leaders of Law and Justice" Polish Political Science Review 7 (1).

Hermet, G (1978) Elections without Choice. Palgrave Macmillan. (Introduction).

Hobson, Christopher (2018) “Democracy: Trap, Tragedy or Crisis?” Political Studies Review Vol 16-1, (pp 38-45).

Huntington, Samuel. 'Democracy’s Third Wave', Journal of Democracy, Spring 1991.

Jankovic, Sava. (2016) "Polish Democracy under Threat? An Issue of Mere Politics or a Real Danger? Baltic Journal of Law \& Politics 9 (1), (pp 49-68).

Kende, Anna \& Kredo, Peter (2019) “Xenophobia, prejudice, and right-wing populism in EastCentral Europe" Current Opinion in Behavioral Sciences 34, (pp 29-33). 
Kopecky, Petr and Muddle, Cas. (2000). "What has Eastern Europe taught us about the democratization literature (and vice versa)?” European Journal of Political Research Vol 37, (pp 517-539).

Levitsky, David and Ziblatt, Daniel (2018). How Democracies Die. New York, Crown. (Introduction)

Levitsky, S. and Way, L. A. (2010). Competitive Authoritarianism: Hybrid Regimes after the Cold War. Cambridge University Press. (Part 1: Introduction and Theory, (pp. 1-84).

Lindberg, I. Staffan. (2009) Democratization by Elections. A New Mode of Transition. The Johns Hopkins University Press. Introduction, chapter 1, (pp 1-47).

Linz, Juan J. and Stepan, Alfred. (1996). Problems of Democratic Transition and Consolidation Baltimore, MD: The John Hopkins University Press (Part 1, Chapters 1-5).

Lowell, Lawrence. (1934) “The Present Crisis in Democracy” Foreign Affairs Vol 12-2, (pp 184-192).

Luhrmann, Anna, and Lindberg, Staffan I. (2019), “A third wave of autocratization is here: What is new about it?" Democratization (pp 1-15).

Lust, Ellen and Waldner, David. (2015). Unwelcome Change: Understanding, Evaluating, and Extending Theories of Democratic Backsliding. Washington, DC: USAID. (pp. 1-14). Mudde, Cas and Kaltwasser, Cristobal Rovira ch.1 "What is populism" (pp. 1-20) and ch. 5 “Populism and democracy” (pp. 79-96) in Populism: A Very Short Introduction (2017). Mufti, Mariam. (2018). "What Do We Know about Hybrid Regimes after Two Decades of Scholarship?" Politics and Governments Vol 6(2), (pp 112-119).

Müller, J. (2016). What is Populism? University of Pennsylvania Press.

Norris, Pippa. (2017). “Is Western Democracy Backsliding? Diagnosing the Risks.” Harvard Kennedy School Faculty Research Working Paper Series. 
Osiatynski, Wiktor. (1996) "The Roundtable Talks in Poland" in the Jon Elster "The Roundtable Talks and the Breakdown of Communism".

Przybylski, Wojciech. (2018) "Explaining Eastren Europe: can Poland's backsliding be stopped?” Journal of Democracy 3 (3), (pp 52-64).

Riaz, Ali. (2020). Voting in a Hybrid Regime: Understanding the 2018 Bangladeshi Election. Palgrave McMillan. Chapters 2 and 5, pp 9-19, (pp.43-56).

Sadurski, Wojciech. (2018) "How Democracy Dies (in Poland): A Case Study of AntiConstitutional Populist Backsliding. Revista Forumul Judecatorilor. (pp 104-178).

Sadurski, Wojciech. (2019) Poland's Constitutional Breakdown. Oxford University Press.

Sanford, George. (2002) Democratic Government in Poland. Palgrave Macmillan. Schmitter, Philippe C., and Karl, Terry L. (1991). "What Democracy Is... and Is Not.” Journal of Democracy Vol 2(3), pp75-88. Staar, F. Richard. (1998) Transition to Democracy in Poland. St. Martin's Press. New York.

Schedler, Andreas. (1998). "What Is Democratic Consolidation?” Journal of Democracy, Apr. 1998.

Schedler, Andreas. (2006a). Electoral Authoritarianism: The Dynamics of Unfree Competition. Boulder: Lynne Rienner. (Chapter 1 and Chapter 2: The logic of electoral authoritarianism / Andreas Schedler; Methodological challenges -- Drawing boundaries: how to craft intermediate regime categories/ Gerardo L. Munck).

Tworzecki, Hubert. (2019) "Poland: a case of top-down polarization" The Annals of the American Academy 681, (pp 97-118).

Way, L. A. (2008). "The real causes of the color revolutions." Journal of Democracy 19(3), (pp 55-69).

Waldner, David and Lust, Ellen (2018) "Unwelcome change: coming to terms with democratic backsliding” Annual Review of Political Science Vol 21, (pp 93-113). 


\section{APPENDIX: JAROSLAW KACZYNSKI AND HIS ROLE IN POLISH POLITICS}

Who is Jaroslaw Kaczynski? Why his name is circulated in all the analysis of Poland, and what role does he play in the country? These questions should be answered i to understand democratic backsliding in Poland, and why I argue that this democratic erosion has brought a rise of the right-wing populist leader and his populist policies. Populism in Poland was not born with the PiS coming to power, but the crucial points about the PiS party's rise to power are the political structure and divisions of power inside the party.

The PiS party was founded by twin brothers Lech and Jaroslaw Kaczynski. As the founders of the political party, the position and role of the Kaczynski brothers have never been the subject of opposition or discussion. Currently, Jaroslaw Kaczynski is the leader and chairman of the party. All party nominations, party policies and decisions are made by the PiS chairman, and he enjoys full freedom in shaping the course of the party (Hartlinski, 2019). On one hand, Jaroslaw Kaczynski is just an average MP and chairman of the party, on the other hand, he is commanding the country without constitutional responsibility and accountability, which makes it a significantly unique case.

The populist character of the current regime has many facets. One of these facets is that the real center of power is one person, Jaroslaw Kaczynski, rather than a constitutionally designated official. The significant role of Kaczynski in the current Polish political system, even though completely invisible to the constitutional design, has been accepted and recognized by foreign politicians as well, who seek meetings with Kaczynski rather than the President or the Prime Minister, because they know that is where the true power resides (Sadurski, 2018, p. 114). For example, in 2016, German chancellor Angela Merkel met secretly with Jaroslaw Kaczynski outside Berlin. In 2018. Rex Tillerson, U.S. Secretary of State, visited the chairman's headquarter during his official trip to Warsaw, breaking the conventional protocol (Przybylski, 2018, p. 58). Unconstrained by the Constitution and public consultation from the beginning, Kaczynski initiated systematic changes that resulted in many cadre appointees who are loyal to Kaczynski and his party. This favoritism, in turn, paved the way to a change in political order, bringing in a neo-patrimonial society, just like in many postcommunist societies (e.g., Russia, Belorussia, or Ukraine).

When it comes to electoral activity, it is crucial to point out the fact that Political Performance Index (PPI) data and Statistical Analysis (ER) show an interesting correlation between individual (Jaroslaw Kaczynski) and party (PiS) performance. In other words, when there is an increase for the PiS party nationwide, the support for Kaszynski is lower (Hartlinski, 2019). This dataset explains the unwillingness of Jaroslaw Kaczynski to run for the dominant state positions, preferring rather to lead the government from the behind. 